\title{
SURVIVAL OF THE FITTEST: HOME EXERCISE, MOVING IMAGE TECHNOLOGY, AND AUDIOVISUAL PRESERVATION
}

by

Olivia Babler
Bachelor of Arts, University of Wisconsin-Madison, 2013

\author{
A thesis \\ presented to Ryerson University \\ in partial fulfillment of the \\ requirements for the degree of \\ Master of Arts \\ in the Program of
}

Film \& Photography Preservation and Collections Management

Toronto, Ontario, Canada

(C) Olivia Babler 2017 


\section{AUTHOR'S DECLARATION FOR ELECTRONIC SUBMISSION OF THESIS}

I hereby declare that I am the sole author of this thesis. This is a true copy of the thesis, including any required final revisions, as accepted by my examiners.

I authorize Ryerson University to lend this thesis to other institutions or individuals for the purpose of scholarly research.

I further authorize Ryerson University to reproduce this thesis by photocopying or by other means, in total or in part, at the request of other institutions or individuals for the purpose of scholarly research.

I understand that my thesis may be made electronically available to the public. 


\begin{abstract}
Survival of the Fittest: Home Exercise, Moving Image Technology, and Audiovisual Preservation Master of Arts, 2017

Olivia Babler

Film \& Photography Preservation and Collections Management

Ryerson University
\end{abstract}

This thesis explores the production, use and preservation of instructional fitness media made in the U.S. between the 1910s and 1980s. While film historiography has expanded to include many non-theatrical, 'orphan' works since the mid-1990s, home exercise-an enormously popular genre of the moving image- has received scant attention from media scholars and preservationists. This is primarily a material history of a genre that has been disseminated on a variety of home-viewing formats since the 1920s, many of which have become obsolete and may soon become inaccessible. Primarily drawing upon contemporary advertisements, reviews and trade publications, as well as conversations with archivists, producers, distributors and collectors, this study seeks to expose the forgotten early iterations of the home exercise genre while also exploring the less-discussed material aspects of the more famous recent examples. 


\section{Acknowledgements}

Thank you to my first and second readers, Dr. Jean Bruce and Professor Marta Braun, for their guidance and wisdom, and to Professor Don Snyder, for his encouragement and endless patience. I would also like to extend many heartfelt thanks to Snowden Becker, Mark Galanty, Arnie Holland, Jeffrey Monseau, Aaron Valdez and Jerry Wagner for taking the time to thoughtfully respond to my questions and for providing me with sometimes unexpected resources and insights.

I am truly grateful to the generous and brilliant Nick Howe Bukowski, who is always happy to read a draft, help me develop a thought, or watch a cheesy workout video. Enormous thanks to Olivia Wong - a video and orphan films pro - who let me bounce countless thesis ideas off of her and continued to provide insightful feedback once I finally picked one. I am also indebted to Hadas Binyamini, who convinced me that home exercise media is a worthy thesis

topic. I am constantly counting my lucky stars that I ended up in Toronto at the same time as the three of you.

Deepest love and gratitude to my parents, Lori Henthorne and Tim Babler, and to the rest of my family in Wisconsin, who have encouraged me even as I decided to move to another country to pursue graduate studies in an obscure field. 


\section{Contents}

List of Figures $\quad$ vi

List of Appendices vii

Introduction 1

1. Literature Survey

2. Moving Beyond Cold Type and Lifeless Illustrations 13

3. A New Epoch in Health Activities 19

4. Body in Broadcast

5. Sculpting with the Stars $\quad 39$

Conclusion $\quad 49$

Appendices $\quad 53$

Bibliography $\quad 56$ 


\section{Figures}

$1 \quad$ An advertisement for Building Up the Health of a Nation (1916), featuring Bernarr Macfadden

2 Part of an advertisement for Pathé Review, including a still from Keep Fit

3 Two frames of $9.5 \mathrm{~mm}$ film, featuring the title card for Churn and Tickle Toe (1924) and displaying $9.5 \mathrm{~mm}$ film's distinctive central sprocket hole

$4 \quad$ Intertitles from Churn and Tickle Toe, displaying the "automatic stop" notches unique to $9.5 \mathrm{~mm}$ film

5-8 A sequence from Churn and Tickle Toe, featuring an animated stick figure and a man performing the "churn" exercise

9-12 A sequence from Churn and Tickle Toe, featuring a woman performing the "tickle toe" exercise

13 Bonnie Prudden demonstrates “exercise 48” in Sports Illustrated in 1958

14 Debbie Drake poses for an article in Radio TV Mirror in 1961

15-18 Stills from a behind-the-scenes featurette about the making of Aerobicise (1981) 40

19 Front and back cover of a used VHS copy of Jane Fonda's Complete Workout 44 (1989) 


\section{Appendices}

Appendix A Advertisement for Bernarr Macfadden's Physical Culture Photo Plays, Inc. from 1917

Appendix B A page from C. Ward Crampton's 1924 film script, detailing “Exercise No. 3"

Appendix C Description of the "Keep Fit" series in the 1926 catalogue of Pathex 


\section{Introduction}

At the sixty-second annual meeting of the National Education Association in July 1924, Dr. C. Ward Crampton announced that he had been developing a series of seven films with Pathé Exchange that were meant to keep America fit. During his address titled "How to Reach the Masses with Health Education," Crampton described his fitness films as "the pioneer effort to put the health gospel on the screen," and confidently declared that if the venture proved successful, "it will be the marking of a new epoch in health activities." ${ }^{2}$ Indeed, in the intervening century since Crampton's address, time-based exercise media has become one of the most commercially and culturally dominant genres of the moving image.

This thesis investigates the production, use and preservation of instructional fitness films in the United States, tracing the genre's migration from film, to television, to video over the course of the twentieth century. Beginning with Bernarr Macfadden in the 1910s and ending with Jane Fonda in the 1980s, the main focus of this study is home exercise media, specifically instructional moving images that encourage physical mimesis from the spectator and are typically consumed in a domestic setting with the goal of weight loss, athletic training and/or improved health. $^{3}$ As an enormously popular and highly unique genre of the moving image, it is ripe for investigation, particularly as the physical formats on which it has been disseminated tumble towards obsolescence and decay. Home exercise media may be at particular risk of degradation and neglect, both because of the now-obsolete carriers on which these moving images have been shared, as well as the cultural and institutional dismissal of this genre as trivial or unworthy of study.

1. "Visual Instruction Program at Washington," Visual Education, July 1924, 205.

2. "7 Health Pictures Ready for Release," Variety, July 1924, 17.

3. In this thesis, I sometimes refer to this genre as "home exercise films" or "fitness films," with "film" meant as a general term for moving images regardless of physical carrier (and so includes works that were recorded on motion picture film, on video, or digitally). 
Guided by the belief that a deeper understanding of how these films, television programs and videos were produced and used can explain their cultural value and justify their preservation, the central inquiries of this study are: How have moving images been used in private spaces as aids to physical self-transformation since the introduction of portable home projectors? Have these media been preserved, and how can moving image archivists be better custodians to home exercise media? To address these questions and reconstruct this history, a variety of primary sources-contemporary advertisements, reviews, trade publications, scripts, catalogues, packaging, and the films, television programs and videos themselves- have been examined. Informal conversations with archivists, producers, distributors and private collectors carried out in spring 2017 have also been vital sources of information about the history and preservation of this genre.

This study is primarily concerned with the material aspects of commercial physical culture media, from creation to obsolescence, and seeks to describe a genre that has been left out of the canon of moving image history despite (or due to) its far-reaching popularity. In addition to placing these films in the industrial context of home viewing technologies and the cultural context of twentieth century attitudes about the body, the present study highlights the challenges and importance of preserving this genre. This thesis therefore intervenes in the standard historical narrative by moving beyond stylistic analysis and asking, what happens to home exercise media both before and after consumption? 


\section{Literature Survey}

Home exercise media constitute a distinctive genre that raises many questions about technology, the body, gender, domesticity, spectatorship and taste, but has nonetheless been largely left out of general media histories. While several authors have explored 1980s and '90s workout videos, there are few instances of this curiosity extending to earlier iterations of the genre, and there has generally been an inattention to the materiality and preservation of these objects. The following literature survey discusses the ways in which this genre has been ignored or misrepresented in scholarly writing, while also highlighting the texts that have served as valuable resources for the present investigation.

Non-theatrical film has received a renewed interest in the last two decades. ${ }^{4}$ Two 2011 anthologies by cinema scholars, Useful Cinema ${ }^{5}$ and Learning with the Lights Off: Educational Film in the United States, ${ }^{6}$ offer helpful historical overviews of instructional films. Edited by Charles Acland and Haidee Wasson, Useful Cinema explores how 16mm film democratized the medium and enabled its instructional use. Due to its wide scope in regard to both time (19001960) and setting (churches, schools, libraries, museums, etc.), the book is able to comprehensively survey the industry's transition from $35 \mathrm{~mm}$ to $16 \mathrm{~mm}$ film. Learning with the Lights Off, edited by Devin Orgeron, Marsha Orgeron and Dan Streible, has a similarly broad approach to educational films (as an "umbrella under which to collect scholarship on films that were used to teach, inform, instruct, or persuade viewers in a variety of ways and contexts"), ${ }^{7}$ but digs deeper into the specifics of the genre's style and auteurs. Though neither book addresses

4. Dan Streible, Martina Roepke and Anke Mebold, “Introduction: Nontheatrical Film,” Film History 19 , no. 4 (2007), 339.

5. Charles Acland and Haidee Wasson, eds., Useful Cinema (Durham: Duke University Press, 2011).

6. Devin Orgeron, Marsha Orgeron and Dan Streible, eds., Learning with the Lights Off: Educational Film in the United States (New York: Oxford University Press, 2011).

7. Orgeron, Orgeron and Streible, "Introduction," 9. 
home fitness films directly, the creative methodologies employed in both volumes have served as inspiration for this project.

Cinema scholar Haidee Wasson's 2009 article "Electric Homes! Automatic Movies! Efficient Entertainment!: Domesticity and the $16 \mathrm{~mm}$ Projector in the 1920s" usefully investigates the ways that the emergence of $16 \mathrm{~mm}$ projectors and screens during the $1920 \mathrm{~s}$ changed the layout of the American home and how families engaged with cinema. ${ }^{8}$ Situating $16 \mathrm{~mm}$ projectors as part of a new "private, domestic ideal," Wasson demonstrates how portable film technologies were linked to a range of automated household appliances that emerged in '20s. She also argues that home viewing technologies "must be understood clearly in relation to the gendered dynamics of the household," and discusses how housewives' operation of film projectors both complicated and reinforced established gender roles. ${ }^{9}$ In highlighting the ways that personal film projectors were tied to the "modern, electrified, commodified home,"10 Wasson effectively links technology to the cultural zeitgeist without succumbing to technological determinism. However, she does not discuss the films themselves, nor does she explore the new ways that small-gauge film enabled instructional and educational films to enter the home.

Introduced in 1922, Pathé Frères's 9.5mm film format was one of the earliest home viewing systems for motion pictures (including exercise films); however, histories of smallgauge film in North America frequently elide "Nine-Five," focusing instead on Kodak's more popular $8 \mathrm{~mm}$ and $16 \mathrm{~mm}$ gauges. An exception is Alan Katelle's 2002 book Home Movies: A History of the American Industry 1897-1979, which provides vital information on the

8. Haidee Wasson, "Electric Homes! Automatic Movies! Efficient Entertainment!: Domesticity and the $16 \mathrm{~mm}$ Projector in the 1920s," Cinema Journal 48, no. 4 (2009), 1-21.

9. Ibid, 19-20.

10. Ibid, 14-15. 
technological aspects of Pathé's $9.5 \mathrm{~mm}$ projector and camera. Here, Katelle helpfully explains the format's unique technical specifications, such as how $9.5 \mathrm{~mm}$ 's "automatic stop" functioned and how amateur filmmakers shot and processed $9.5 \mathrm{~mm}$ film in the United States. As Katelle is primarily interested in amateur movie-making, the commercial films released for home consumption on this gauge fall outside the scope of the book.

Communications scholar Richard Lewis Ward's 2016 book When the Cock Crows: A History of the Pathé Exchange offers detailed discussion of Pathé's American subsidiary's business models, but spends little time on the small-gauge releases of the company. ${ }^{11}$ Acknowledging that much of the business's history is murky and undocumented, Ward's book is the only published history of Pathé Exchange. Drawing upon business records, trade journals, and correspondences, Ward's book traces the history of Pathé Exchange from its beginnings in France in 1908 to its merger with RKO in 1931 to the eventual drawn-out dissolution of PathéAmerica in 1968. While Ward offers an extensive filmography of Pathé Exchange's productions, the $9.5 \mathrm{~mm}$ exercise films C. Ward Crampton made with Pathex are not mentioned.

Popular culture scholar Michael Schoenecke's short 2005 article "Bobby Jones, Golf, and His Instructional Reels"12 is a rare example of scholarly analysis of pre-video instructional sports films. Schoenecke details professional golfer Bobby Jones's motives for making twelve one-reel instructional golf films with Warner Brothers in the 1930s. Most of the article is spent on biography of Jones' golf career, with a small amount of description of the films' storylines and some criticism of the accuracy of Jones's advice and form (the films' instructional value). While Schoenecke does include important historical context about the role of sport in American culture

11. Richard Lewis Ward, When the Cock Crows: A History of the Pathé Exchange (Carbondale, IL: Southern Illinois University Press, 2016).

12. Michael Schoenecke, "Bobby Jones, Golf, and His Instructional Reels," Film \& History 35, no. 2 
at the time, he does not offer any information on the films' distribution or audience, nor does he tie Jones's films to the broader instructional film genre.

Turn-of-the-century physical culturist Bernarr Macfadden has been the subject of a number of publications, ${ }^{13}$ but his foray into filmmaking is frequently a footnote in a larger story about his eccentric tendencies, scandalous personal life and wildly successful print periodicals. In the 1989 biography Body Love: The Amazing Career of Bernarr Macfadden, historian William R. Hunt wisely declares that Macfadden "pioneered the physical training genre that has since become part of the standard video and TV program fare."14 Hunt, however, does not dedicate much text to backing up this claim, as his book is more concerned with Macfadden's other publishing pursuits. Shanon Fitzpatrick's 2013 doctoral dissertation “Pulp Empire: Macfadden Publications, Transnational America, and the Global Popular"15 discusses Macfadden's films at greater length, but zeroes-in on his True Story Pictures rather than his earlier filmmaking endeavours with Physical Culture Photo Plays.

While instructional fitness films, television programs and videos are not generally mentioned in broad media histories, they are occasionally explored in books about physical culture. Journalist Jonathan Black's 2013 book Making the American Body: The Remarkable Saga of the Men and Women Whose Feats, Feuds and Passions Shaped Fitness History usefully contextualizes The Jack LaLanne Show and fitness guru Bonnie Prudden's various

13. For example: Robert Ernst, Weakness Is a Crime: The Life of Bernarr Macfadden (Syracuse, NY: Syracuse University Press, 1991); Ann Fabian, "Making a Commodity of Truth: Speculations on the Career of Bernarr Macfadden," American Literary History 5, no. 1 (1993), 51-76; Kathleen L. Endres, "The Feminism of Bernarr Macfadden: Physical Culture Magazine and the Empowerment of Women," Media History Monographs 13, no. 2 (2011).

14. William R. Hunt, Body Love: The Amazing Career of Bernarr Macfadden (Bowling Green, $\mathrm{OH}$ : Popular Press, 1989), 158.

15. Shanon Fitzpatrick, "Pulp Empire: Macfadden Publications, Transnational America, and the Global Popular” (PhD diss., University of California, Irvine, 2013). 
accomplishments within the Cold War mindset of the 1950s. ${ }^{16}$ Aimed at a general audience, Black's book is mostly concerned with biography (as indicated by its title), and offers only brief descriptions of the television programs themselves. Similarly, science journalist Gina Kolata's 2003 book Ultimate Fitness: The Quest for Truth About Exercise and Health offers a general history of fitness myths and fads in the U.S. starting in the 1890s, and includes a small amount of useful information about LaLanne and his contemporaries. ${ }^{17}$

Scholar Shelly McKenzie's 2013 book Getting Physical: The Rise of Fitness Culture in America offers an impressively detailed history of both national and local television fitness programs in the 1950s and ' 60 s, linking their popularity to a new American fear of obesity. ${ }^{18}$ Her chapter on weight-loss television programs pays particular attention to how women engaged with the shows, reporting on how exercise programs did and did not solve "the problem with no name" ${ }^{, 19}$ for the mid-century housewife. McKenzie acknowledges the difficulty of researching the topic, calling physical culture "a field that often leaves little in the way of a paper trail, ${ }^{20}$ and she mostly relies on newspaper articles and fan letters from the era to flesh out the history. She also acknowledges the preservation status of these shows, lamenting that the majority of the programs are no longer available for study. While McKenzie's book stretches from the 1950s to the present day, she breezes past ' 80 s workout videos and does not link them to the television programs that came before them.

Scholarly writing about domestic viewing technologies has largely ignored the home fitness genre despite its unique relationship to consumer media players. General histories of the

16. Jonathan Black, Making the American Body: The Remarkable Saga of the Men and Women Whose Feats, Feuds and Passions Shaped Fitness History (Lincoln: University of Nebraska Press, 2013).

17. Gina Kolata, Ultimate Fitness: The Quest for Truth About Exercise and Health (New York: Farrar, Straus \& Giroux, 2003).

18. Shelly McKenzie, Getting Physical: The Rise of Fitness Culture in America (Lawrence: University Press of Kansas, 2013).

19. Betty Friedan, The Feminine Mystique (New York: W.W.Norton, 1963).

20. McKenzie, 6. 
home video industry tend to leave out "made-for-video" releases, instead focusing on either Hollywood productions released on video, the VCR's time-shifting abilities, or the home video "format battles" between Betamax and VHS. For example, media studies scholar Frederick Wasser provides a basic linear history of home video technologies with a focus on the distribution of Hollywood films in his 2002 book Veni, Vidi, Video: The Hollywood Empire and the $V C R .^{21}$ While he examines VHS as a mass medium, he does not offer any sustained discussion of fitness videos (despite their dominance in the industry), nor does he engage with the larger socio-cultural impacts of the technology.

More recent investigations of video by media scholars have taken narrower approaches. Michael Z. Newman's 2014 book Video Revolutions: On the History of a Medium is more concerned with how the categorization and cultural status of video have changed since the 1940s. ${ }^{22}$ Most relevantly, he explains that "While the VCR was later feminized by some of its uses in the home, in its early years it was marketed as advanced technology for male consumers. [...] As a gadget for men's active use, video would be a departure from the feminized, passive medium of TV." ${ }^{, 3}$ While they are alluded to here, Newman's book fails to mention home exercise videos even once. Lucas Hilderbrand's 2009 book Inherent Vice: Bootleg Histories of Videotape and Copyright is more useful, in that it engages with the medium-specific attributes of video in a way that the previously mentioned authors do not, linking tape degradation aesthetics and nostalgia. ${ }^{24}$ This book is primarily concerned with the legal issues surrounding bootlegging, however, and only briefly mentions home exercise videos.

21. Frederick Wasser, Veni, Vidi, Video: The Hollywood Empire and the VCR (Austin: University of Texas Press, 2002).

22. Michael Z. Newman, Video Revolutions: On the History of a Medium (New York: Columbia University Press, 2014).

23. Ibid, 48.

24. Lucas Hilderbrand, Inherent Vice: Bootleg Histories of Videotape and Copyright (Durham, NC: Duke University Press, 2009). 
Cultural studies scholar Ann Gray's 1992 book Video Playtime: The Gendering of a Leisure Technology is an ethnographic examination of gender politics in relation to home viewing practices, but surprisingly makes no mention of home fitness videos either, despite their highly gendered nature and huge popularity. ${ }^{25}$ Like Newman, she situates home video as a leisure activity that has been gendered as masculine, portraying women of the 1980 s as reliant on their husbands to both choose the programming and operate the technology. As in Veni, Vidi, Video, Gray's book situations VHS use as an outgrowth of Hollywood film culture, as opposed to in relation to other industries such as television, fitness, etc. That said, Gray's book is an interesting contribution because she discusses how actual, as opposed to theoretical, women engaged with this technology. Her argument that gender and domestic labour/leisure divisions must be examined in order to understand the cultural role of television and video in the household in the 1980s and ' 90 s is a critical intervention.

In addition to a handful of insightful non-academic articles that have been written about the genre in a recent wave of ' 90 s nostalgia, ${ }^{26}$ a number of scholars have published on fitness videos and their stars, usually from a sociopolitical, feminist perspective. Elizabeth Kagan and Margaret Morse were likely the first to explore the genre from a scholarly perspective, with their 1988 article "The Body Electronic_-Aerobic Exercise on Video: Women's Search for Empowerment and Self-Transformation," a sociological study about how women engaged with instructional aerobics videos in the late 1980s. ${ }^{27}$ Kagan and Morse focus on Jane Fonda's New Workout (1986), applying both a cultural studies lens as well as movement analysis to discuss the

25. Ann Gray, Video Playtime: The Gendering of a Leisure Technology (Abingdon, UK: Routledge, 1992). 26. For example: Phil Daoust, "A History of Fitness Fads," The Guardian (2011); Emily Yoffe, "Exercise Time Warp," Slate (2011); Carrie Battan, "Thank You, Jane Fonda: A Brief History of America's Obsession With Workout Videos," Grantland (2015); Jake Rossen, "How 'Jane Fonda's Workout' Conquered the World," Mental Floss (2015).

27. Elizabeth Kagan and Margaret Morse, “The Body Electronic: Aerobic Exercise on Video: Women's Search for Empowerment and Self-Transformation,” TDR 32, no. 4 (1988), 164-80. 
"postmodern feminine condition" evidenced in workout videos.

Media studies scholar Hilary Radner uses a Foucauldian approach in her chapter in Constructing the New Consumer Society (1988), "Producing the Body: Jane Fonda and the New Public Feminine. ${ }^{, 28}$ Radner applies Michel Foucault's ideas about surveillance and the "docile body" to understand why physical fitness became a "central discourse of feminine culture" around the time of the release of Jane Fonda's Workout Book (1981). ${ }^{29}$ She provides an impressive amount of historical context to illuminate the aerobics craze of the 1980s, using her understanding of the cultural milieu to intelligently link women's new-found desire to exercise with societal "demands" for public discipline. ${ }^{30}$

Kinesiology scholar Margaret MacNeill's chapter “Sex, Lies, and Videotape: The Political and Cultural Economies of Celebrity Fitness Videos" (1997) applies John Fiske's (1987) codes of media to examine celebrity fitness videos. ${ }^{31}$ She analyzes Jane Fonda's Step Aerobic and Abdominal Workout, Cher's Body Confidence and Cindy Crawford's Shape Your Body (all released in 1992) at the level of reality, representation and ideology. MacNeill, a physical education expert, also evaluates the technical aspects of the fitness routines using the health and safety standards of the National Fitness Leadership Advisory Committee. ${ }^{32}$ In addition to performing a stylistic analysis of the three videos (commenting on editing rhythms, camera angles, music choices, etc.), MacNeill examines marketing campaigns, video jacket design, and magazine reviews in order to understand fitness videos as a "mechanism of power."33 She concludes that workout videos largely offer pseudo-scientific discourse to promote

\footnotetext{
28. Hilary Radner, "Producing the Body: Jane Fonda and the New Public Feminine," in Constructing the New Consumer Society, ed. Pekka Sulkunen, et al. (London: Pelgrave Macmillan, 1997).

29. Ibid, 111.

30. Ibid, 110.

31. Margaret MacNeill, "Sex, Lies, and Videotape: The Political and Cultural Economies of Celebrity

Fitness Videos," in Sport and Postmodern Times, ed. Geneviève Rail (Albany: SUNY Press, 1998).

32. Ibid, 169-171.

33. Ibid, 180.
} 
patriarchal ideologies about women's worth being linked to weight loss. MacNeill's piece is also thorough in regard to the distribution and economic impact of these videos, but there is no discussion of the videos' production or preservation contexts.

In "Resisting Venus: Negotiating Corpulence in Exercise Videos," authors Antonia Losano and Brenda A. Risch also analyze the content and filmic construction of home exercise videos, arguing that they are "one of the most successful contemporary media for the production and transmission of the new ideals for female form. ${ }^{, 34}$ Appearing in the 2001 book Bodies Out of Bounds: Fatness and Transgression, this chapter specifically grapples with how overweight women are represented in and interact with the genre. Vanessa Russel also performs stylistic analysis of celebrity workout videos in her chapter "Make Me a Celebrity: Celebrity Exercise Videos and the Origins of Makeover Television" in the book Makeover Television: Realities Remodeled (2007). ${ }^{35}$ She argues for workout videos to be seen as precursors to the popular makeover television genre, but is surprisingly ahistorical about the roots of exercise media. For example, Russel misleadingly claims that the introduction of video meant that, for the first time, "activities that could once only be done in public could now be done in viewers' homes,"36 ignoring decades of filmed and televised fitness routines meant for domestic viewing.

Of what has been written on the genre, Lucas Hilderbrand's 2010 article 'Sweatin' Out the Shame" is particularly insightful into the highly complex nature of the workout video. ${ }^{37}$ Here, Hilderbrand mainly engages with queer theory to dissect the genre, specifically his own conflicted feelings about Richard Simmons. This piece is worthy of emulation for the nuanced

\footnotetext{
34. Antonia Losano and Brenda A. Risch, "Resisting Venus: Negotiating Corpulence in Exercise Videos," in Bodies Out of Bounds: Fatness and Transgression, eds. Jana Evans Braziel and Kathleen LeBesco (Berkeley: University of California Press, 2001), 113. 35. Vanessa Russel, "Make Me a Celebrity: Celebrity Exercise Videos and the Origins of Makeover Television," in Makeover Television: Realities Remodeled, ed. Dana Heller, (New York: I.B.Tauris, 2007). 36. Ibid, 67.

37. Lucas Hilderbrand, "Sweatin' Out the Shame," Flow 11, no 12 (2010), http://flowtv.org/?p=4971.
} 
way that Hilderbrand explores the repetitive, "physically mimetic type of spectatorship" 38 inherent to the genre, and the way that the "cultural degradation of the workout video has become ever-more intertwined with the physical degradation of the VHS format." ${ }^{\prime 39}$ That said, this short piece does not discuss the materiality of the medium beyond aesthetics.

To conclude, what has been written on home exercise media generally examines the visual style, ideological aims and cultural context of celebrity fitness videos, leaving the material aspects of the genre largely unexplored. Pre-video examples of home exercise media have additionally generally fallen outside the scope of these studies. By discussing the formally distinctive precursors to the workout video, this thesis will correct some of these lacunae as well as debunk the widely-held assumption that participatory fitness media only emerged with the coming of VHS. This thesis will build on the work of these scholars, with an aim of linking developments in home viewing technologies with changes in instructional fitness media.

38. Hilderbrand, "Sweatin' Out the Shame," paragraph 3.

39. Ibid, paragraph 1. 


\section{Moving Beyond Cold Type and Lifeless Illustrations}

Called the "greatest living exponent of physical culture," 40 bodybuilder Bernarr Macfadden was instrumental in cultivating America's turn-of-the-century fascination with fitness by engaging a variety of media. With rapid industrialization and urbanization taking place, Americans' relationship to their own bodies was undergoing a dramatic shift as the nineteenth century drew to a close. Middle- and upper-class lifestyles had become increasingly sedentary, as many Americans enjoyed more free time and less work-mandated physical activity. Macfadden founded Physical Culture magazine in 1899, offering tips on how the newly-softened American could obtain a more toned physique, accompanied by halftone illustrations of sculpted bodies as proof of the power of exercise. ${ }^{41}$ Coinciding with Theodore Roosevelt's tenure as a physically active president (1901-1909), a new emphasis on fitness as a means for the improvement of society and the "white race" emerged, ${ }^{42}$ and Macfadden's publications frequently invoked the rhetoric of racial hierarchy. ${ }^{43}$ He encouraged fasting and exercise as a means of regaining the "superb virility of manhood," which he believed the white American man had lost with the emergence of modern comforts. ${ }^{44}$

After developing a fan base, Macfadden starred in a series of instructional fitness films called Building Up the Health of a Nation in 1916. The moving, muscular body had been the focus of the cinematic gaze before: Eadweard Muybridge famously photographed the human and animal body in motion in the 1880s, and Étienne-Jules Marey’s films for the French army were

40. Motion Picture News, January 1916, 528.

41. Fabian, 62.

42. McKenzie, 4. See also Theodore Roosevelt, "The Strenuous Life," 1899.

43. R. Marie Griffith, Born Again Bodies: Flesh and Sprit in American Christianity (Berkeley: University of California Press, 2004), 129.

38. Bernarr Macfadden, Superb Virility of Manhood: Giving the Causes and Simple Home Methods of Curing the Weaknesses of Men (Spotswood, NJ: Physical Culture Publishing Co., 1904). 
meant to instruct soldiers on improved physical form. ${ }^{45}$ The spectacular body had also played a prominent role in the "cinema of attractions," with actuality films such as Edison's Sandow (1894) astonishing spectators with displays of physical feats. But as technological and creative developments lead to longer film lengths, Macfadden's theatrical series had the ability to be instructive in a new way. As an advertisement in Motion Picture News (fig. 1) described the appeal and novelty of the series:

At last it has been accomplished. Bernarr Macfadden in Universal Pictures, in a series of health exercises that will delight his army of followers throughout the world.

You have followed and profited by the health exercise talks and illustrations in Bernarr Macfadden's famous PHYSICAL CULTURE magazine; now you have the opportunity of seeing the exercises demonstrated by Bernarr Macfadden himself in moving pictures.

Every two weeks a lesson in Health Building will be shown in all Universal theatresconsisting of the pictures by Bernarr Macfadden, and complete instructions which enable you to practice them just exactly as he does.

Not in cold type and lifeless illustrations, but in animated moving pictures-personal lessons that would cost you a large sum if demonstrated for you personally or exclusively. ${ }^{46}$

45. Marta Braun, Picturing Time: The Work of Etienne-Jules Marey (1830-1904) (Chicago, IL: University of Chicago Press, 1994), 39.

46. Motion Picture News, January 1916, 528. 


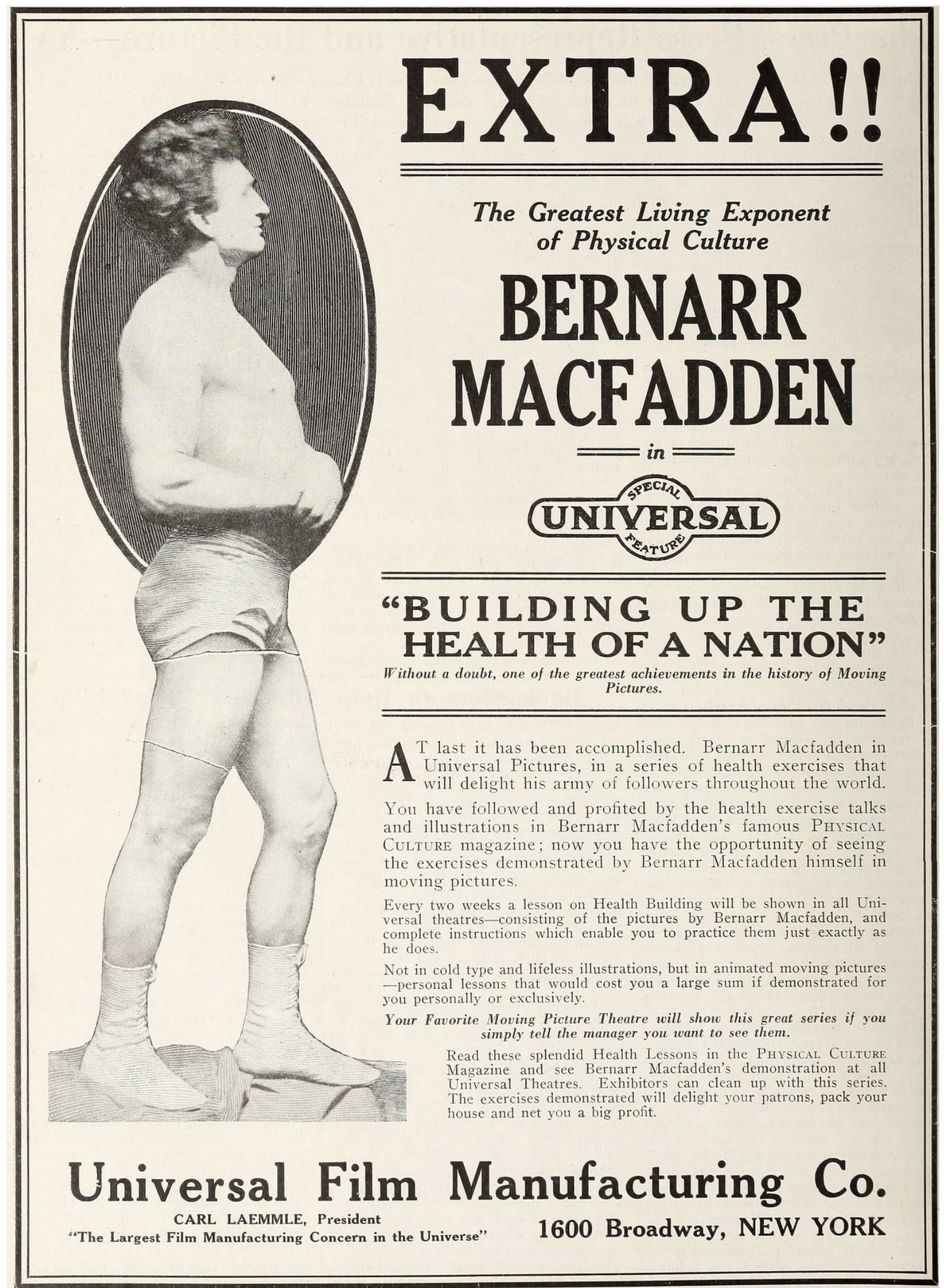

Figure 1. An advertisement for Building Up the Health of a Nation (1916), featuring Bernarr Macfadden. Source: Motion Picture News, January 1916, 528. Digitized by the Media History Digital Library, http://archive.org/stream/motionpicturenew131unse\#page/528/. 
Positioned as a societal good, Building Up the Health of a Nation had similarities to the propagandistic "preparedness serials" that had been gaining traction in U.S. theatres since 1914. While most of these films invoked patriotic rhetoric to emotionally brace audiences for possible American entry into World War I, ${ }^{47}$ Building Up the Health of a Nation was innovative in that it attempted to physically prepare filmgoers. Using his celebrity status to attract an audience, Macfadden was a trusted authority whom audiences likely felt comfortable emulating. Emphasizing the unique affordances of the relatively new technology of cinema, Macfadden recognized the ways in which moving images could be a superior teaching tool for fitness than his "cold" and "lifeless" magazines had been, producing one of the first examples of an instructional fitness film made for a general audience.

With a heightened physical training culture taking over as the U.S. joined Allied forces in Europe, Macfadden began producing Physical Culture Screen Magazine in 1917. ${ }^{48}$ Again making educational use of the medium, the series aimed to illustrate "muscular poses, wrestling, deep breathing, gymnastic exercises for girls, classical dancing, laughing as an exercise, and recreative exercises for children," with the aid of some of America's "best known masculine and feminine athletes. ${ }^{\circ 9}$ Macfadden's directorial debut for the series, Zongar, the Dare-devil of Romance (1918), was a five-reel "athletic melodrama" starring stuntman George Larkin. In an appeal to censors who had demanded changes to the film, Macfadden explicitly tied maintaining a healthy body—and watching his films — to patriotism:

47. Kalton C. Lahue, Continued Next Week: A History of the Moving Picture Serial (Norman, OK: University of Oklahoma Press, 1969), 38.

48. See Appendix A.

49. "Macfadden Screen Magazine,” The Moving Picture World, November 1917, 1010. 
'Zongar' is a physical preparedness drama. It stands side by side with every effort which is now being made to win the war. In the beginning of this war four-fifths of our men were rejected as defective by the army physician. You cannot view 'Zongar' without squaring your shoulders, without drawing in a deep breath. It teaches a lesson of splendid manhood, strong capable womanhood. ${ }^{50}$

Zongar was a box office bomb and received middling reviews. ${ }^{51}$ F.G. Spencer of Motion Picture News called it "Macfadden propaganda"52 while the reviewer for Moving Picture World declared that it had "particular appeal just at this time, when the question of physical preparedness is so much in evidence, and its needs emphasized by the war." ${ }^{, 53}$ As with $75 \%$ of feature films from the silent era, ${ }^{54}$ Zongar is now considered a 'lost' film. ${ }^{55}$

During the 1920s, Macfadden's recommendations entered the domestic sphere, as radio broadcasting expanded enormously during the decade. The post-war ' 20 s are frequently described as the Golden Age of Sport, with both watching and participating in athletic events becoming popular leisure activities for wealthy Americans. ${ }^{56}$ The time was ripe for Macfadden to host his own morning exercise program on WOR-AM out of Newark, New Jersey beginning in 1923. ${ }^{57}$ Enabling listeners to exercise in the privacy of their own homes, Macfadden conducted callisthenic routines over the airwaves for seventy-five minutes each morning beginning at 6:45, urging listeners to write in to have illustrated charts mailed to them. ${ }^{58}$

Similarly, exercise phonograph records by Wallace Rogerson, Walter Camp and Dr. John Harvey Kellogg (of cornflakes fame) were circulated heavily beginning in 1920, providing

50. Bernarr Macfadden, cited by "Nine Changes Ordered in 'Zongar," Motion Picture News, In the Independent Field, March 1918, 1600.

51. Ernst, 87.

52. F.G. Spencer, "Zongar," Motion Picture News, February 1918, 737.

53. “'Zongar' Has Timely Appeal,” The Moving Picture World, June 1918, 1601.

54. David Pierce, The Survival of American Silent Feature Films: 1912-1929 (Washington, DC: Council on Library and Information Resources, 2013).

55. "Zongar / Bernarr Macfadden [motion picture]," Library of Congress, American Silent Feature Film Database, accessed June 2, 2017, http://memory.loc.gov/diglib/ihas/loc.mbrs.sfdb.10920/default.html.

56. Kolata, 41.

57. Fitzpatrick, 171.

58. Eric Bornouw, A Tower in Babel: A History of Broadcasting in the United States to 1933 (New York: Oxford University Press, 1966), 168. 
guided fitness routines accompanied by music to keep listeners moving in tempo. While Camp's routines were largely targeted at a male demographic, Rogerson's records, such as "Get Thin to Music" (1920), were marketed towards women, with ads declaring "it's PLAY to take INCHES off the hips this MODERN way!"59 As also seen in an advertisement for Kellogg's "Health Ladder," which implored retailers to "sell the idea that exercise is health - and exercise with music is pleasure, ${ }^{, 60}$ physical fitness was increasingly cast as an enjoyable hobby (made more enjoyable through capitalism and technology), rather than as a moral duty. While there is clearly no single point of origin for the genre, these records and broadcasts were perhaps the beginning of the use of time-based media for exercise in the home.

59. "Wives With Hips," Photoplay Magazine, November 1924, 123.

60. Talking Machine World, November 1923, 16-17. 


\section{A New Epoch in Health Activities}

Like MacFadden, Dr. Charles Ward Crampton_an influential physician and leading expert on Geriatrics and Gerontology_believed that moving images were key to reaching the masses and changing American health behaviours. As he wrote in Child-Welfare Magazine in 1924, Crampton considered motion pictures to be "the most effective method of reaching the great mass of people in the United States," but believed previous health pictures had failed because they were "not sufficiently interesting to compete with Gloria Swanson and Mabel Norman." ${ }^{, 61}$ Crampton thought he could do better, and began scripting fitness scenarios for Pathé Exchange in 1923.

Crampton's films taught routines from his book Physical Exercise for Daily Use ${ }^{62}$ such as the "star gazer," the "tickle toe" and the "churn," demonstrated by both animated stick figures and live-action actors. In addition to illustrating the seven recommended exercises, the films gave physiological justifications for the movements and provided cultural-historical context (e.g., 'this is a modern scientific improvement on the four thousand year old 'kundalani' [sic] movement"). ${ }^{63}$ For added flair, the routines were introduced with "elaborate historical settings from Egyptian, Greek, Assyrian and medieval times" and explained by scenes of scientific apparatuses in medical laboratories. ${ }^{64}$ Crampton boldly claimed, "no expense has been spared to make these pictures attractive," as he hoped his films would be appealing enough to "make the people want to go home and try the exercises themselves." 65

First announced during the "Visual Instruction" program at the National Education

61. C. Ward Crampton, "Physical Education," Child-Welfare Magazine, August 1924. Cited by "Among the Magazines," The Educational Screen, September 1924, 271.

62. C. Ward Crampton, Physical Exercise for Daily Use (New York: G.P. Putnam's Sons, 1924).

63. C. Ward Crampton, "Script for film on Physical Culture Series," 1923, 5, http://cdm16122.contentdm.oclc.org/cdm/compoundobject/collection/p15370coll2/id/17494/rec/2

64. Crampton, "Physical Education," cited by Educational Screen, 271.

65. "7 Health Pictures Ready for Release," 17. 
Association in summer 1924, Crampton's productions were exhibited theatrically as part of the Pathé Review cinemagazine that fall. Produced by Emanuel Cohen and released every other week, Pathé Review consisted of short "scientific, athletic, industrial, scenic and instructive" films, which were shown before features in theatres. ${ }^{66}$ Installments of Crampton's "Series of Seven Scientific Set-Ups" were bundled with other informative (but unrelated) documentary shorts: Pathé Review No. 41 included Keep Fit! followed by a Pathécolor travelogue about Madison, Wisconsin and The Hook Hunters of Hawaii; No. 47 featured Crampton's How to Keep Your Engine Running Right sandwiched between Flying Over Hawaii and The Wood Thrush; and No. 51 included Your Long Life Muscles preceded by Agriculture à la Mode and a film about Providence, Rhode Island. ${ }^{67}$ Keep Fit! also appears to have been released in the U.K. as part of Pathé Pictorial No. 627—Britain's version of Pathé Review—in $1930 .{ }^{68}$ Crampton's films were additionally made available for educational use in health clubs: after viewing the first four films in the series, the Young Womens Christian Association endorsed the films, saying they could be used "very advantageously" during Health Weeks at the Association. ${ }^{69}$

As seen with Macfadden's films, motion pictures had been employed for educational and instructional use before, but this sort of physical training film was viewed as both pioneering and important. An advertisement for Pathé Review in Film Daily from 1924 (fig. 2) described Crampton's series as ground-breaking: "Here is a series of health picture that's entirely new-

66. Catalogue of Pathépictures Selected for Educational, Religious and Social Groups (New York: Pathé Exchange, Inc., 1925), 5.

67. Catalogue of Pathépictures, 54.

68. This is likely, but difficult to confirm. British Pathé dates a film in their collection called Keep Fit as from 1916 and BFI lists a Pathé Pictorial film called Keep Fit as from 1930. The British Pathé film includes demonstrations of Crampton's exercises "the pump," "the kick-up," "the churn," "the tickle toe," and "the stargazer," and features the same stick figure man as Crampton's films, making it almost certainly a Crampton film from 1924, possibly re-cut ("Keep Fit," British Pathé, http://www.britishpathe.com/video/keep-fit/). It also features the logo for Pathé Pictorial, and BFI's description of Pathé Pictorial No. 627 (released 1930) includes a film called Keep Fit, though there is no description of the film's contents or creator ("Keep Fit," British Film Institute, http://collections-search.bfi.org.uk/web/Details/ChoiceFilmItems/153065779).

69. Jane Bellows, cited in "National Board of Y.W.C.A. Laud 'Keep Fit,"” Exhibitor's Trade Review, October 1924, 48. 
new because they are practical, can be remembered and applied. Health preservation is a duty which is widely preached. Its importance is attested by the attention given it in the big magazines and papers. These pictures are interesting." ${ }^{, 70}$ There was clearly something different about the function of this series, as films that did not merely entertain but could also affect quality of life in a less fleeting manner. Pathé Exchange fancied itself as a leader in this sort of film, with its catalogue claiming it had "always recognized the importance of the motion picture as an educational and social force." ${ }^{, 71}$ Adding further credibility to the films, advertisements highlighted that the films had been given the stamp of approval by the officers of both the American Medical Association as well as the National Congress of Mothers and Parent-Teacher Associations. ${ }^{72}$

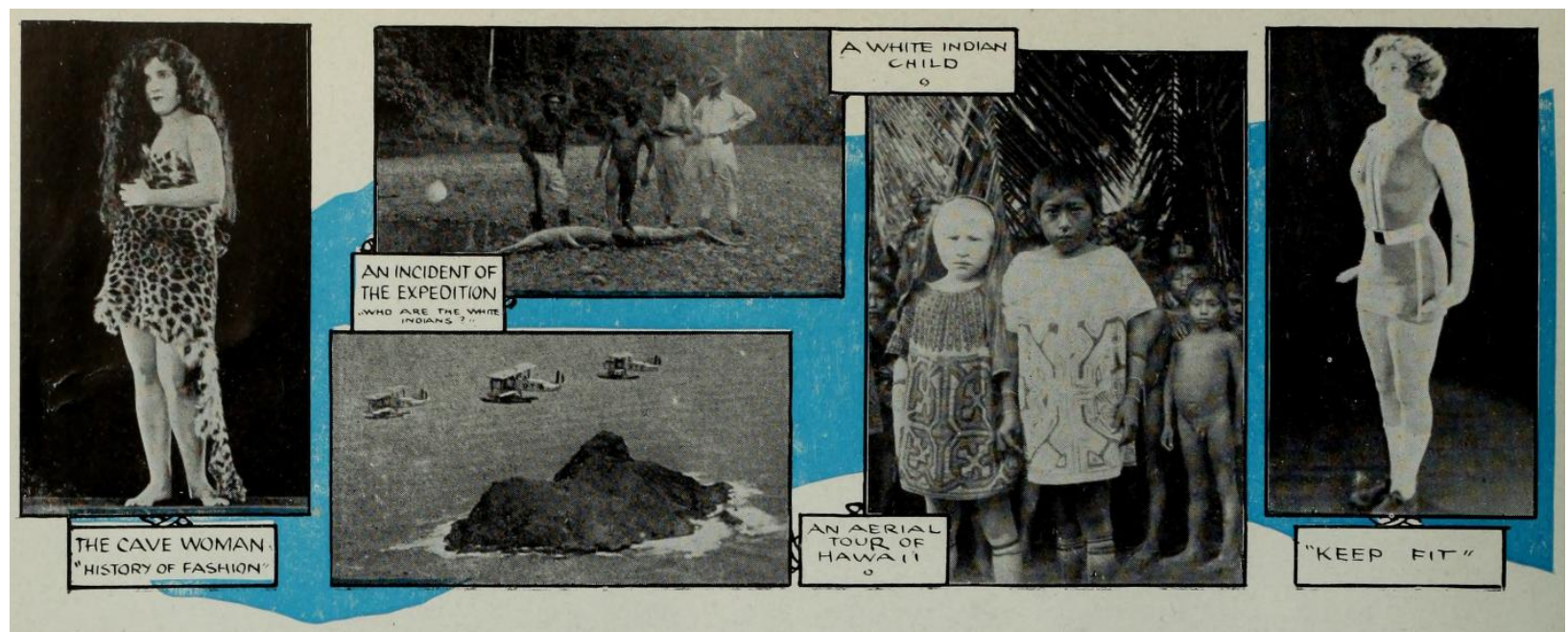

Figure 2. Part of an advertisement for Pathé Review, including a still from Keep Fit (far right).

Source: "Now at Last You Can Get Big Feature 'Stories' in Lengths You Can Play," Film Daily, September 1924, iv. Digitized by the Media History Digital Library, http://archive.org/stream/filmdaily2930newy\#page/n169/.

Crampton, it seems, was a name Pathé Exchange believed Americans could trust with their health. Crampton's role in creating the series was mentioned frequently in the films' 1924, iv

70. “Now at Last You Can Get Big Feature 'Stories' in Lengths You Can Play,” Film Daily, September

71. Catalogue of Pathépictures, 4.

72. "7 Health Pictures Ready for Release," 17. 
promotion, with his professional and scholarly credentials emphasized. Crampton was the auteur of the films, after all; his scripts included not only descriptions of routines, but also of mise-enscène such as costumes, set design and camera distances for putting his exercises on screen. ${ }^{73}$ Before making films, Crampton had written several books and magazine articles about fitness, many of which made extensive use of photographs to demonstrate proper physical form and its links to health. ${ }^{74}$ The fact that he had been Physical Director of New York Public Schools was also mentioned in nearly every advertisement for the films, as he had been instrumental in establishing school fitness and hygiene programs in the 1910 s. $^{75}$

Pathé Exchange released re-edited and retitled versions of Crampton's fitness films on $9.5 \mathrm{~mm}$ safety film in 1926, at a time when film projectors had become automated, portable and affordable enough to enter the newly-electrified home. ${ }^{76}$ Kodak's $16 \mathrm{~mm}$ gauge had entered the U.S. market in 1923, revolutionizing amateur filmmaking and becoming the medium of choice for non-theatrical film distribution. Pathé Frères had introduced $9.5 \mathrm{~mm}$ film a year earlier in France, with the aim of making their films available for domestic viewing for a more affordable price than their previously-manufactured $28 \mathrm{~mm}$ film. ${ }^{77}$ Pathé brought its $9.5 \mathrm{~mm}$ projector (and later, camera) to North America in 1925, rebranding it "Pathex" for American consumers after three years of success in Europe with the name "Pathé Baby." The projector could cast the films onto a wall or screen up to three-feet-by-four-feet with maximum clarity. ${ }^{78}$

Described in Motion Picture News as "one of the most important developments in recent

73. See Appendix B.

74. Rebecca Overton, "Finding Aid: C. Ward Crampton Papers 1920-1952" (Springfield, MA: Springfield College Archives and Special Collections, 2012), 6.

75. Ibid, 5-6.

76. Wasson, "Electric Homes," 5.

77. Katelle, 68.

78. "Motion Picture Outfit for Home Use Placed on Market by Pathex Inc.," Motion Picture News, August 1925,1070 . The projector weighed a very portable 5 pounds, and was $12 \frac{1 / 2}{}$ " tall with a $3 \frac{3 / 4}{4}$ " by 7 " base. 
years in the field of motion-picture equipment, ${ }^{, 79} 9.5 \mathrm{~mm}$ film has several unique features. Its single, central sprocket hole between each pair of frames (fig. 3) gives it an image size and aspect ratio nearly the same as $16 \mathrm{~mm}$, which has perforations on each side of the image ${ }^{80}$ Its clever "automatic stop" for intertitles (fig. 4) also made the format about half as expensive as Kodak's amateur gauge. ${ }^{81}$ As described by Motion Picture News, a notch cut into the side of the film "halts the movement of the film at such frames as contain sub-titles and holds the film in check until the spectator has had time to peruse the reading matter., ${ }^{, 82}$ For example, while a textheavy image projected on $16 \mathrm{~mm}$ film would require eighty frames for five seconds of screen time, the same image on $9.5 \mathrm{~mm}$ film required only about two frames for the same amount of time on screen, "thus effecting an immense saving in footage over the standard projection." Because the Pathex projector was equipped with a low-wattage twelve-volt lamp, the film did not burn or melt in the gate while paused. One disadvantage to the Pathex system was that film was purchased spooled onto closed bobbins, which limited the length of each reel to about sixty feet, or three-and-a-half minutes. ${ }^{84}$

79. Ibid.

80. Ibid. Each frame on a strip of $9.5 \mathrm{~mm}$ film measures $1 / 4$ by $3 / 8$ inch, giving it a $1: 1.31$ aspect ratio. 81. Katelle, 69.

82. "Motion Picture Outfit for Home Use," 1070.

83. Ibid.

84. Ward, 131. 

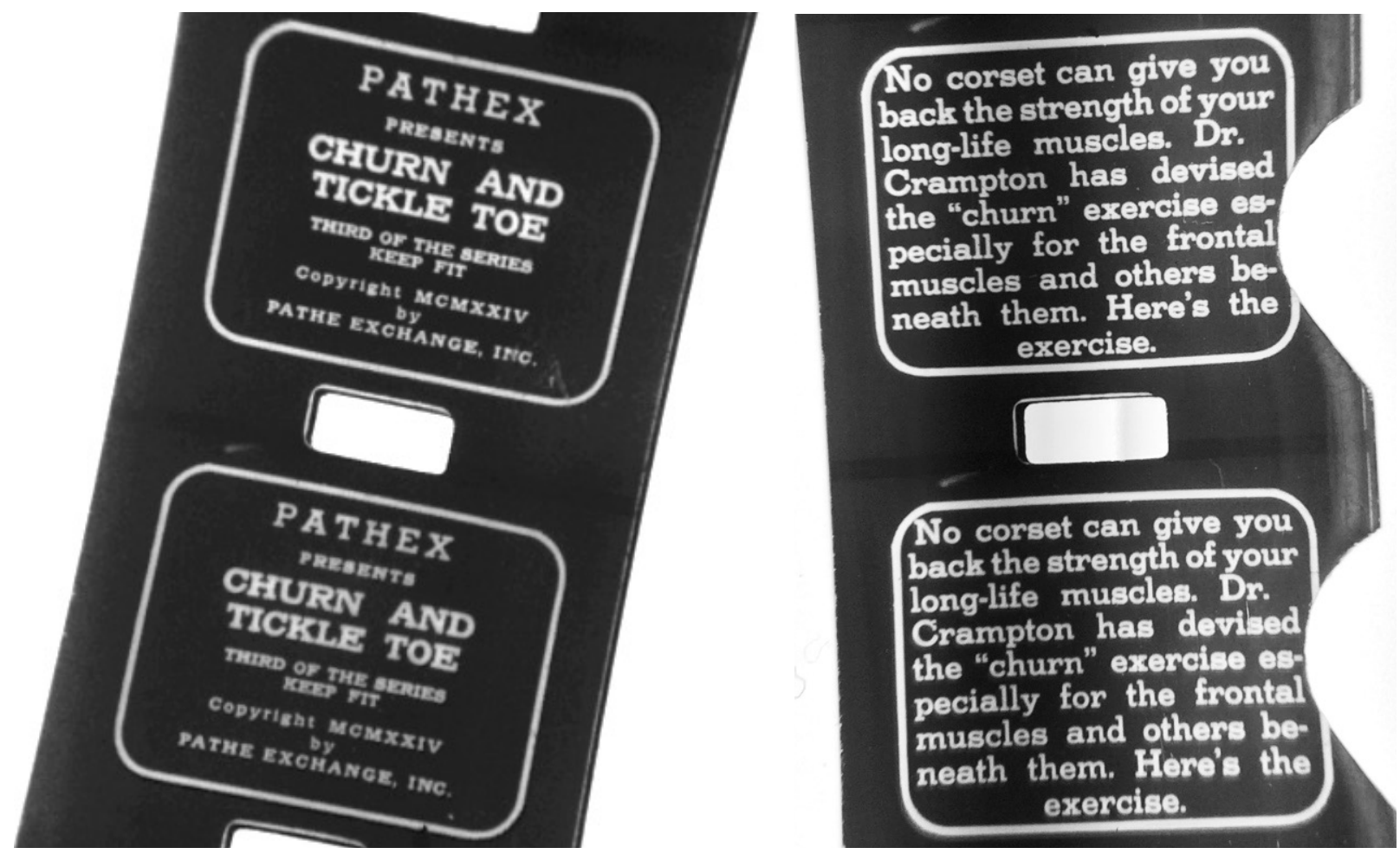

Figure 3 (left). Two frames of 9.5mm film, featuring the title card for Churn and Tickle Toe (Crampton, 1924). Figure 4 (right). Two frames from Churn, displaying the "automatic stop" notches unique to $9.5 \mathrm{~mm}$ film.

Along with Harold Lloyd comedies, travelogues and other educational films, Pathex had an entire "Exercise" category for its $9.5 \mathrm{~mm}$ films. Crampton's films appeared in each Catalog of Pathex Motion Pictures for the Home until 1929, listed on a page titled "Learn to Exercise at Home." ${ }^{\prime 85}$ Under the general title "Keep Fit," the individual titles of Crampton's five filmsStretch and Keep Well, Pump and Kick Up, Churn and Tickle Toe, Pep Steps and Fresh Air and Pep — suggested that the viewer could obtain increased energy and vitality by imitating what they saw on screen. In addition to Crampton's films, the other films in the "Exercise" category were Grantland Rice Sportlights, short films such as Golf Form and Tennis Form that showed "fast and slow motion views ... so that every movement can be studied and reproduced." ${ }^{\circ 6}$ According to Visual Education writer Frank M. Freeman, "Films That Analyze Motion," such as these, had

85. See Appendix C.

86. Pathex, Inc., "Grantland Rice Sportlights and Features Devoted to General Sports and Athletics from Pathé News and Pathé Review," Catalog of Pathex Motion Pictures for the Home (1926), 31. 
been used for athletic training as they allowed viewers to analyze motion that occurs at too quick a rate to appreciate in real-time. ${ }^{87}$ This kind of motion picture was not new, as seen with Marey and others; what was unique was that buyers could now watch and mirror the movements in their own homes, where the films were "always at hand to enjoy whenever you like." 88

The third film in the "Keep Fit" series, Churn and Tickle Toe, took advantage of the unique possibilities of the visual medium, using live action models, animation and artistic double exposures to teach viewers. The Pathex catalogue claimed, "watching this reel is far superior to the daily dozen by phonograph or radio for it shows you exactly what to do, ${ }^{, 9}$ suggesting a hierarchy of the senses with sight at the top. The series was advertised in direct competition with the exercise records that came before them; while a certain amount of interpretation was required while listening to exercise records, Crampton's "home-training lessons" were able to model correct form in a way that albums could not. For example, the "churn" exercise is demonstrated in three different ways, starting with a simple stick figure. The film then likens efficient exercise to machinery: an expository intertitle instructs the viewer to "Do the 'churn' when you arise. Remember to keep your head steady - and rotate the trunk of your body like a carpenter's augur!" [sic] and then cuts to a close-up of muscular forearms cranking the drilling device, followed by a dissolve into a shirtless male model mimicking the motion (figs. 5 through 8 ):

87. Frank N. Freeman, “Types of Educational Motion Pictures," Visual Education, September 1923, 205.

88. Pathex, Inc., Catalog of Pathex Motion Pictures for the Home (1926), 2.

89. Pathex, Inc., "Learn to Exercise at Home," 25. 

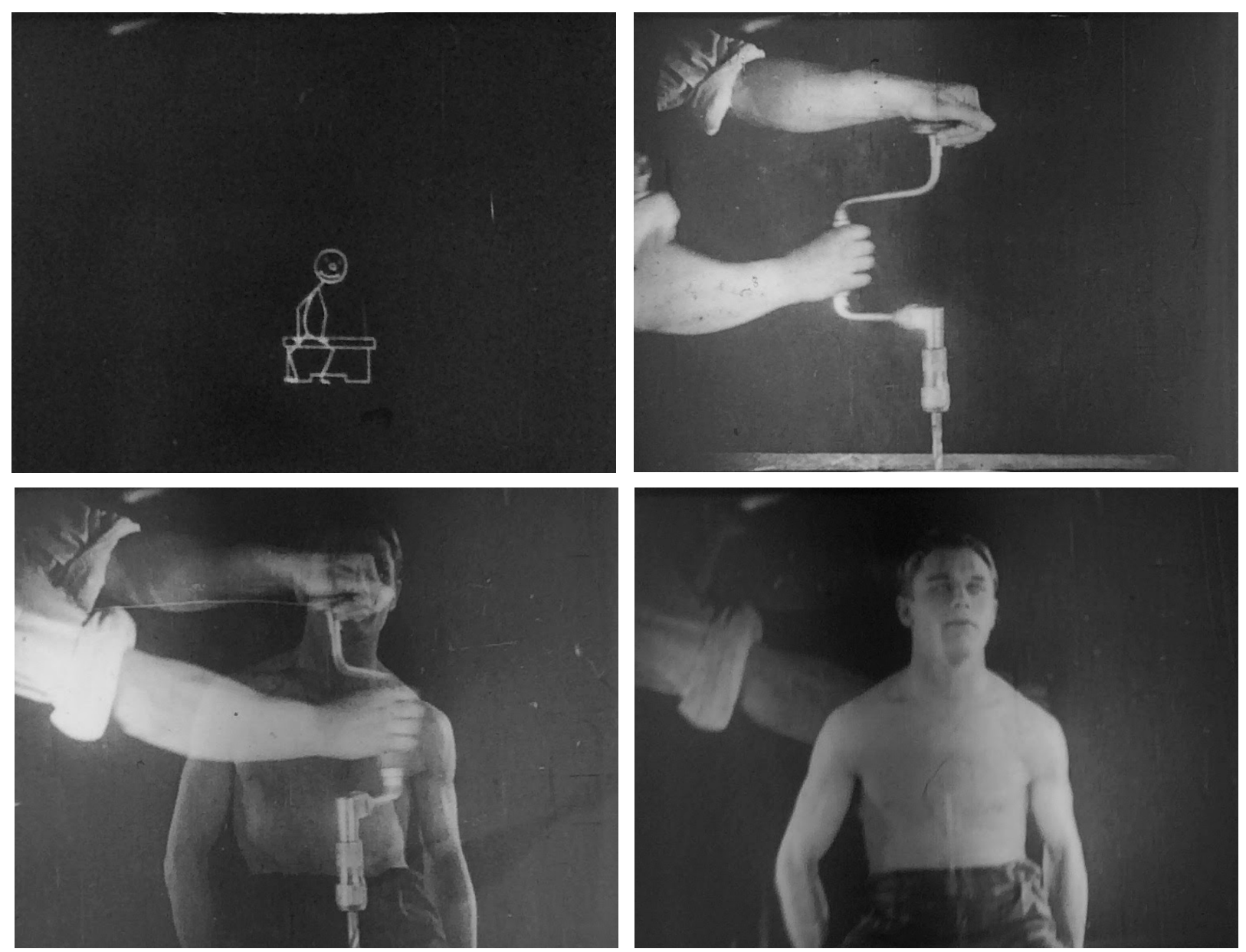

Figures 5-8. A sequence from Churn and Tickle Toe, featuring an animated stick figure performing the "churn" exercise followed by a carpenter's auger dissolving into a shirtless man performing the same motion.

Churn and Tickle Toe employs a combination of demonstrative long shots and close-ups that make it easy to follow, conventions that would go on to define the genre in the 1980 s. The "tickle toe," which consists of "two aeroplane swings and a switch of the hand from the rear down to the toe, $" 90$ is performed by a woman in a sleeveless tank top and mid-thigh shorts, first in long shot then followed by a medium close-up of her legs (figs. 9 through 12). Crampton's scripted intertitles, such as "Try it yourself now-keeping in time with the model,",91 demonstrate how the films' creator likely envisioned viewers imitating the actors as the films

90. Crampton, "Script for film on Physical Culture Series," 3, http://cdm16122.contentdm.oclc.org/cdm/compoundobject/collection/p15370coll2/id/17494/rec/2.

91. Ibid, 5. While this was in the pre-production script for exercise number 2 ("the pump"), it may not have made it into the final cut of Pump and Kick Up. 
played. The Pathex projector was described in 1925 as being "so simplified as to be almost automatic,"92 so it is plausible that the viewer would have been able to step away to follow along with the three-minute routines. The film ends with a motivating intertitle that demands, "Don't forget how it's done and do it!"
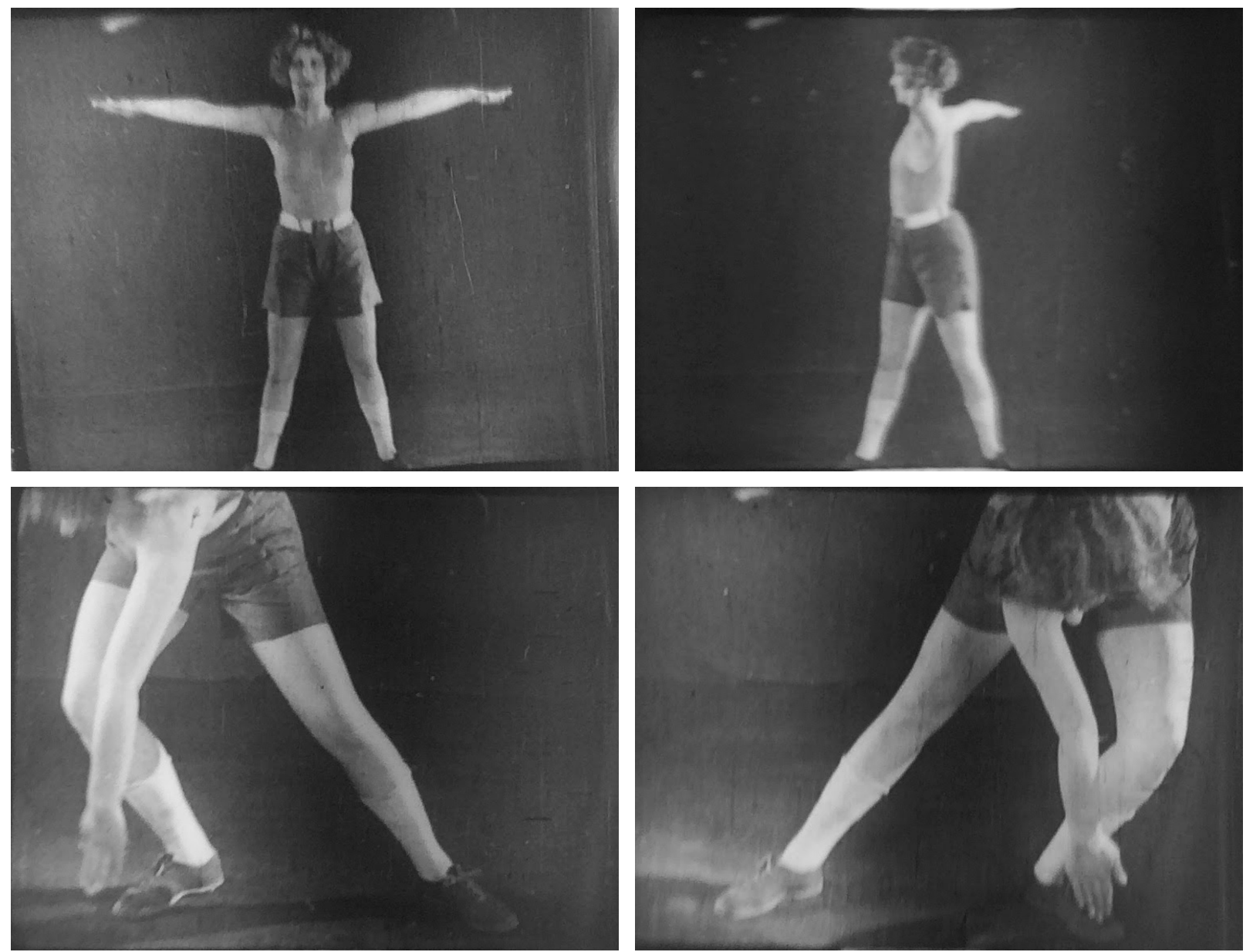

Figures 9-12. A sequence from Churn and Tickle Toe, featuring a woman performing the "tickle toe" exercise, first in long shot and then in MCU of her legs.

Crampton's series was advertised to wealthy urban men, and were described as being "calculated to be of inestimable value to the business man who is unable to give the time to the gymnasium, links, tennis court or riding path."93 The total cost for the Pathex system would have

92. "Motion Picture Outfit for Home Use," 1070.

93. Pathex, Inc., "Learn to Exercise at Home," Catalog of Pathex Motion Pictures for the Home (New York: Pathé Exchange, Inc., 1926), 25. 
likely put it out of range for the average working-class consumer, even within the economic context of the "Roaring '20s." Pathex projectors cost $\$ 50$ at the time (about $\$ 690$ USD in 2017) and each of Crampton's three-minute films cost $\$ 1.75$ (about $\$ 24$ today). Exercising for leisure was already a distinction of class, as physically demanding labour was increasingly relegated to rural areas and the working class. Only $54 \%$ of the American population lived in electricallypowered dwellings in August 1926, ${ }^{94}$ and rural communities did not have widespread access to electricity in the home until the Rural Electrification Act of 1936, so the use of personal projectors for exercise was likely an urban phenomenon.

During the Great Depression, technologies such as home projectors became luxuries that few Americans could afford. ${ }^{95}$ Interest in personal fitness also largely faded during this period, only re-emerging after World War II. ${ }^{96}$ While instructional fitness films returned to the big screen in the 1930s when professional golfer Bobby Jones made twelve shorts for Warner Brothers called "How I Play Golf,"97 small-gauge home exercise films appear to have left the market. Nine-and-a-half-millimeter film never reached its European-levels of success in the U.S., and was more-or-less dealt a death-knell when Eastman Kodak introduced 8mm film in 1932. While the smaller gauge had significantly poorer resolution than $9.5 \mathrm{~mm}$, it was more affordable and had the strong commercial power of Kodak in its favour. ${ }^{98}$ Pathé Exchange started releasing its educational films on $16 \mathrm{~mm}$ starting in the late 1920s (rebranding them as Pathégrams), and merged with RKO Radio Pictures to become RKO Pathé in 1931, after struggling to adapt to the

94. A.T. Cupler, "Rural Electrification in the United States," Editorial Research Reports 1926, vol. III (Washington, DC: CQ Press, 1926), 683, accessed June 14, 2017,

http://library.cqpress.com/cqresearcher/cqresrre1926083000.

95. Wasson, "Electric Homes," 12.

96. Jan Todd, cited by Kolata, 41.

97. One advertisement referred to them as "the shorts New York critics called "the most successful screen merger of entertainment and education"” (Motion Picture Herald, May 1931, between pages 18 and 19).

98. While Kodak had its own library of $16 \mathrm{~mm}$, and later $8 \mathrm{~mm}$, "Kodascope" films available for home use during this time, it does not appear to have released any home exercise films beyond a couple sports form films (similar to Grantland Rice Sportslights). 
sound era. ${ }^{99}$

While most of Pathé Exchange's silent releases are considered lost, ${ }^{100}$ the fact that Crampton's films were released on $9.5 \mathrm{~mm}$ stock has given them an extended lifeline. Although the format is unable to be projected or digitized without specialized equipment that is scarce in North America, the acetate film base used for release prints on this gauge is significantly more stable than the nitrate originals. Nine-and-a-half-millimeter release prints of two of Crampton's films-Pump and Kick $U p^{101}$ and Churn and Tickle Toe ${ }^{102}$-are held at UCLA's Film \& Television Archive, but as a consumer format, most $9.5 \mathrm{~mm}$ films from this era have wound up in the hands of private collectors rather than in cultural heritage institutions. For example, Jerry Wagner, self-proclaimed owner of the world's largest collection of $9.5 \mathrm{~mm}$ films and equipment, ${ }^{103}$ obtained most of his collection (including all five Crampton films) through an estate sale. ${ }^{104}$ Pathex films frequently show up on collectibles websites such as eBay, usually for around $\$ 5$ each.

Although versions of his films have survived against the odds, Crampton's filmmaking accomplishments have essentially been forgotten. Crampton is remembered for his written publications (including his column in Boy's Life in the 1930s) and his contributions to the medical field (such as developing the Crampton Test for Fatal Shock), but his pioneering films do not appear to be mentioned in any history of instructional film or physical culture, nor are

99. Ward, 120.

100. Ward, "Filmography," 1, http://siupress.siu.edu/books/978-0-8093-3496-4.

101. "Pump and kick up. [192-]," UCLA Library Catalog, accessed April 30, 2017, http://cinema.library.ucla.edu/vwebv/holdingsInfo?bibId=107094.

102. "Churn and tickle toe. [192-]," UCLA Library Catalog, accessed April 30, 2017, http://cinema.library.ucla.edu/vwebv/holdingsInfo?bibId=15002.

103. Jerry Wagner, "Pathex.com," accessed April 25, 2017, http://www.pathex.com.

104. Jerry Wagner, e-mail message to author, February 7, 2017. 
they mentioned in his New York Times obituary. ${ }^{105}$ Rebecca Overton's highly-detailed finding aid to Crampton's collection of papers at Springfield College Archives \& Special Collections notes "an interesting packet of Crampton's exercises along with stage commands which could have been the beginning process of putting his exercises on film or television," ${ }^{106}$ but the endproduct of these scripts is conspicuously absent from mention. One reason for this may be that there is no single repository for Pathé Exchange's films or business records, making their productions difficult to research. ${ }^{107}$ Additionally, only one of Crampton's films-the Pathé Pictorial version of Keep Fit—has been made available online, digitized by British Pathé without any reference to Crampton. ${ }^{108}$

105. "Dr. C. Ward Crampton is Dead," New York Times, October 22, 1964, http://www.nytimes.com/1964/10/22/dr-c-ward-crampton-is-dead.html.

106. Overton, 11.

107. Ward, 6.

108. "Keep Fit," British Pathé, http://www.britishpathe.com/video/keep-fit/. 


\section{Body in Broadcast}

Crampton's vision of preaching the "health gospel" to the masses would soon be manifested through the new technology of commercial television, which emerged in the late1940s and transformed the space of the household while reshaping leisure for Americans. But while Crampton's "Keep Fit" series had offered advice on how to improve strength and energy to businessmen, the television stars of the $1950 \mathrm{~s}$, ' $60 \mathrm{~s}$ and '70s promised thinness and attractiveness to housewives during their popular daytime programs. Largely returning to the domestic sphere after entering the workforce during World War II, many suburban women found themselves with national television stars like Jack LaLanne, Bonnie Prudden and Debbie Drake to keep them company. By 1962, many advertisers had discovered that there was "considerable box office appeal in sponsoring programs that convert the female viewer's bulges into alluring curves," according to an article in Sponsor from that year. ${ }^{109}$ The article-aptly titled "TV's Great Bust-and-Chest Boom"-continues, "if things continue at the present rate, "America the Lazy' will soon turn into 'America the Beautiful."”

Television made home-based exercise easier and more accessible than it had ever been. Fitness programs popped up in droves during the 1950 s and ' 60 s, and emerged as an identifiable genre. Unlike home projectors, television sets were ubiquitous: by 1960, fifty million American households owned a television. ${ }^{110}$ While television viewers were at the mercy of broadcast schedules, and could only watch their favourite stars at certain times of day (usually morning), televised fitness programs had many advantages over Crampton's films. The amount of time and energy involved in initiating the programs was reduced, as one could simply flip a switch to turn on the television versus setting up a screen and threading a projector. The televised programs

109. “TV's Great Bust-and-Chest Boom," Sponsor, October 1962, 42.

110. McKenzie, 42. 
were much longer than Crampton's three-minute films, usually fifteen minutes to a half-hour, encouraging an extended workout. They also had the benefit of synchronized sound, which helped participants keep in-time with routines even if they were not physically able to look at the screen due to multitasking or performing an awkwardly-positioned stretch.

The Jack LaLanne Show was the most famous and long-running of these fitness programs, debuting locally on San Francisco's ABC affiliate KGO-TV in 1951. With bulging muscles under his signature tight-fitting jumpsuit and bouncy organ music serving as a metronome to his repetitive movements, LaLanne evangelized fitness to his faithful followers. His exercises were not particularly strenuous; instead, LaLanne emphasized beauty, speaking of weight reduction and improved attractiveness - he even had segments teaching "facial exercises" to reduce the appearance of wrinkles and tighten drooping skin. Airing five mornings a week, the show became nationally syndicated in 1959 when Mobile Video Tapes Inc. began recording the show with RCA cameras and Ampex tape recorders. ${ }^{111}$ Syndication quickly made The Jack LaLanne Show accessible to $50 \%$ of the U.S. population, ${ }^{112}$ and it aired on network television for twenty-six years.

While LaLanne generally encouraged viewers to use everyday household items such as brooms and kitchen chairs in their fitness routines, he also attached consumer goods to improved health and made product placement a large component of the show. According to Sponsor, trade deals for The Jack LaLanne Show called for each station to give LaLanne two minutes of advertising time for his own products during broadcasts of the show. ${ }^{113}$ LaLanne used this time to promote his "Woman's Trimsuit," "Exclusive Formula Shampoo," "Face Exerciser," and

111. "New TV-Tape Firm," Broadcasting, May 1959, 83.

112. Black, 42.

113. Henry C. Akerberg, cited by "TV's Great Bust-and-Chest Boom," 54. 
"Glamour Stretcher," of which he reportedly sold forty-thousand a month. ${ }^{114}$ In a 1962 pamphlet sent to viewers who purchased his products, LaLanne justified the product hawking as necessary to keeping his show on-air:

Why I sell La Lanne products when I should be concentrating $100 \%$ on my message of 'physical fitness through exercise.' The answer is simple. No one pays me to do my daily tv show. It is very costly to buy tv time for five half-hour shows each week, and because we are not on a network, each station carrying the show must have films or tapes to play. This too is very costly. The original filming - the hundreds of film prints, production charges, shipping to stations - it all costs a lot of money. Thus, the only way I can bring you my daily half-hour show is through the sale of products I believe in. ${ }^{115}$

While LaLanne had a local show before she did, mountaineer Bonnie Prudden was the first to host regular exercise spots on national television, starting in 1956. Prudden believed television was " $65 \%$ responsible" for Americans' poor health, ${ }^{116}$ and used her weekly exercise segments on CBS's Home Show and NBC's The Today Show to counter the trend. ${ }^{117}$ Prudden had been director of the Institute for Physical Fitness in White Plains, New York, and her research was influential in the creation of the President's Council on Youth Fitness in 1956. ${ }^{118}$ Prudden wrote and modeled fitness advice in a syndicated column in Sports Illustrated starting the following year, in short pieces that also advertised her television spots (fig. 13). In 1961, she filmed two new series with Hal B. Cook Associates: Keep Fit, Be Happy (a daily half-hour exercise and conditioning segment) and Relax With Bonnie Prudden ("a late 5-minute relaxation spot"). ${ }^{119}$ A decade later, she released an instructional "filmstrip kit" with Pathescope Educational Films, which included five films, five records, a teacher's manual and a script. ${ }^{120}$ In

114. Black, 41.

115. "TV's Great Bust-and-Chest Boom," 54.

116. Ibid, 56.

117. Harriet Segman, "Forever Young," TV Radio Mirror, June 1959, 60-63.

118. Bonnie Prudden, "How to Get More Out of Life," Sports Illustrated, August 1957, 36.

119. "Exercise series," Broadcasting, Programming, January 1961, 68.

120. Copyright Office, "Books and Pamphlets Including Serials and Contributions to Periodicals, Current Registrations A-L, January-June 1972," Catalog of Copyright Entries: Third Series 26, no. 1 (Washington, DC: 
addition to making films, videos and television appearances, Prudden released six exercise albums, wrote fifteen health books, and launched her own fitness fashion line. ${ }^{121}$

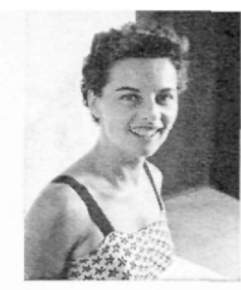

BONNIE PRUDDEN/Fitness

Arms, rope and a bell

48 climbing a rope will tone flabby arms,

Last month Bonnie showed you how to start exercising on a rope, swinging on it and pulling yourself up from the floor (SI, Sept. 29). Now you are ready to climb it. When you first attempt the climb, don't try going all the way to the top. Even if you made it, you might burn your hands by coming down too fast. For incentive, mark the rope off in feet so you can see how far you've progressed. When you are able to reach the top, try placing a bell there. You can win the undying admiration of your child with your ability to ring the bell.

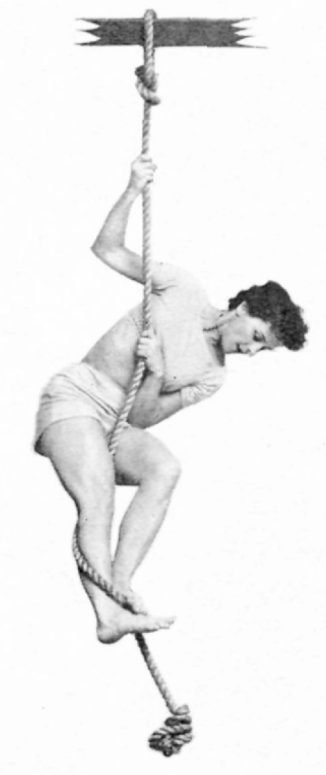

Hook right leg so rope lies over right foot. Pull up with arms, knees bent. Clamp left loot on

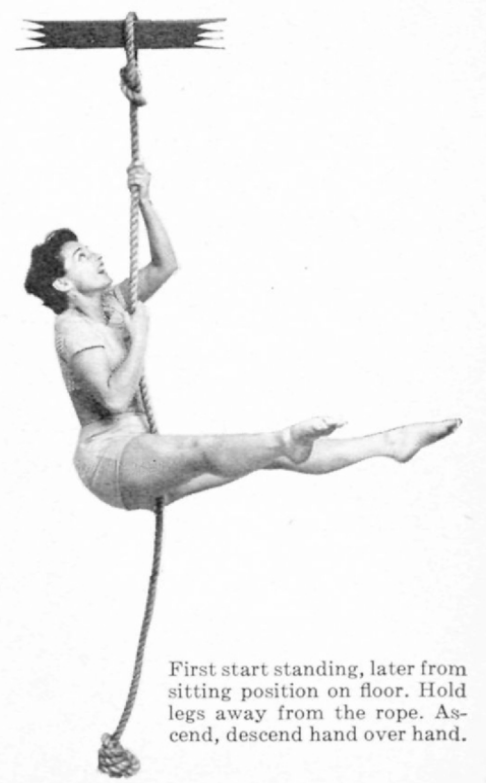

Figure 13. Bonnie Prudden demonstrates "exercise 48" in Sports Illustrated in 1958. Source: Bonnie Prudden, "Arms, rope and a bell," Sports Illustrated (October 1958), 56, https://www.si.com/vault/issue/41201/1/3.

Library of Congress, 1974), 821.

121. Black, 47. 
While Prudden was an athlete and health expert, Debbie Drake was an aspirational sex symbol in a collared leotard (fig. 14). Originally produced by Banner Films for WISH-TV (Corinthian Broadcasting Corporation's Indianapolis station), The Debbie Drake Show's fifteenminute episodes of "planned exercises, diet suggestions, beauty tips and good health habits"122 began airing in 1960 . The show was an "overnight sensation," 123 and was nationally syndicated in 106 U.S. and Canadian markets by October $1962 .{ }^{124}$ An article about Drake in Variety from 1961 snarkily began, "The U.S. is probably the only country in the world history to suffer a national obesity problem, and a trim chick named Debbie Drake (like a true new frontierwoman) is doing something about it—while fattening her own bankroll." ${ }^{125}$ An advertisement for Corinthian quoted one Drake fan as saying, "It's so much easier to exercise when you have company, ${ }^{, 126}$ reflecting Drake's appeal as a peer rather than an authority figure.

Like LaLanne and Prudden, Drake was able to parlay her television success into an established brand. She wrote books and a syndicated fitness column in The New York Herald Tribune and recorded several exercise albums, which allowed her fans to work out with her even when her television program was not airing. Her 1964 instructional fitness album "How to Keep Your Husband Happy" is representative of both Drake and LaLanne's messaging-fitness was increasingly about re-enforcing gender roles and helping women maintain a conventionally appealing figure. Drake's second television show, a thirty-minute dance-instruction program called Debbie Drake's Dancercize, ${ }^{127}$ was a predecessor to the rhythmic aerobics craze of the 1980s. It was syndicated in 1968 and ran for ten years, right up to the beginnings of video.

122. Broadcasting Telecasting, April 1961, 73.

123. Robert McConnell, cited by "TV's Great Bust-and-Chest Boom," 42.

124. “"Debbie Drake' Sales," Variety, Local TV \& Syndication, March 1962, 25.

125. “... Of Curves, Charts \& Debbie Drake," Variety, June 1961, 25.

126. "Local TV Program Exercises Prerogative, Gets Syndicated," Sponsor, May 1961, 6.

127. Clarence Petersen, "How Velda Louise Bellah Became TV's Debbie Drake," Chicago Tribune, February 15, 1970, accessed May 29, 2017, http://archives.chicagotribune.com/1970/02/15/page/438/article/howvelda-louise-bellah-became-tvs-debbie-drake/ 


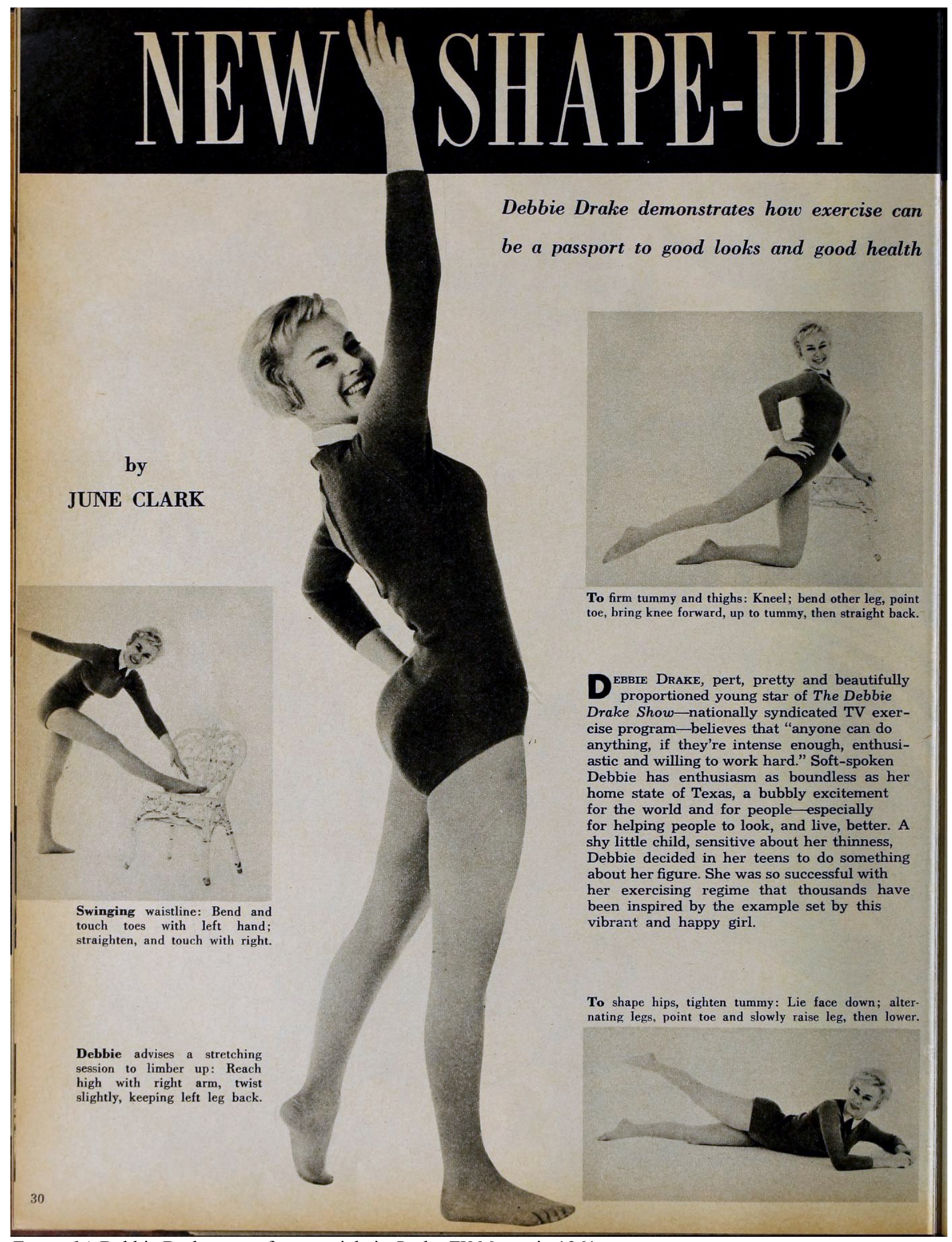

Figure 14. Debbie Drake poses for an article in Radio TV Mirror in 1961.

Source: June Clark, "New Shape-Up," Radio TV Mirror (September 1961), 30-31.

Digitized by the Media History Digital Library, http://archive.org/stream/radiotvmir00ma\#page/n247/. 
Despite being highly popular and unique, these programs have received scant attention from media scholars. As an inherently domestic format, television was, and continues to be, characterized as a passive and feminine technology, film's "low other." ${ }^{128}$ But the reason for the academic neglect of these shows seems linked to a lack of cultural legitimization combined with an unavailability of archival sources. According to Shelly McKenzie, "relatively little footage of these early television exercise shows exists today because they were considered too ephemeral to conserve." ${ }^{129}$ In the early 1950 s, television was broadcast in direct transmission, with kinescope (film) recordings only made of those programs that were to be re-aired. While 2" videotape was used to record programs beginning in 1956, raw stock videotape was expensive, leading many stations to erase and record over old broadcasts; this practice contributed to the loss of "thousands of hours of programming" from the era. ${ }^{130}$ While many networks realized in the " $60 \mathrm{~s}$ that archiving their broadcasts could have monetary benefits, syndicated shows generally had no such protector. Even for those programs that were recorded, few institutions have the equipment to transfer 2" videotape to a new master in order to make them accessible to researchers. ${ }^{131}$

While LaLanne had many successful contemporaries, his programs remain accessible in a way that theirs do not, potentially obscuring that they ever existed. For example, 130 episodes of The Jack LaLanne Show were re-aired on ESPN Classic in 2003 and 2004; director of programming and acquisitions Crowley Sullivan called LaLanne "an American treasure," and claimed that without him, fitness video star Jane Fonda "might be answering phones for John

128. Michele Hilmes, "The Bad Object: Television in the American Academy," Cinema Journal 45, no. 1 (2005), 111-17. See also Keir Keightley, "Low Television, High Fidelity: Taste and the Gendering of Home Entertainment Technologies," Journal of Broadcasting \& Electronic Media 47, no. 2 (2003), 236-59.

129. McKenzie, 71.

130. Sam Kula, Appraising Moving Images: Assessing the Archival and Monetary Value of Film and Video Records (Lanham, MD: Scarecrow Press, 2003), 17.

131. Margaret A. Compton, "The Archivist, the Scholar, and Access to Historic Television Materials," Cinema Journal 46, no. 3 (2007), 129-30. 
Kerry."132 BeFit Enterprises, run by Jack's widow Elaine LaLanne, has diligently preserved episodes of his show, and released fifty episodes on "Collector's Edition" DVDs in 2005. The packaging claims that the episodes had "not been commercially viewed in over forty plus years" and that "each show has been painstakingly restored to its original broadcast standard."133 UCLA's Film \& Television Archive holds copies of twenty-six episodes of The Jack LaLanne Show (out of over three thousand) on both $16 \mathrm{~mm}$ film and 2" videoreel, ${ }^{134}$ though the airdates for most episodes are unknown. UCLA also holds one $16 \mathrm{~mm}$ preservation copy of an episode of The Bonnie Prudden Show from 1961, likely saved because Ted Kennedy was interviewed during the episode. ${ }^{135}$ Although Drake filmed hundreds of episodes of exercise programs, only a small handful of preserved copies still exist. These are largely in the hands of private film collectors such as Ira Gallen, whose collecting hobby turned into a successful stock footage business for '50s and ' 60 s television that does not exist anywhere else. ${ }^{136}$

132. Cited by Richard Sandomir, "TV SPORTS; Jack LaLanne Is Back (Sort Of), Helping Viewers Feel Guilty Again," New York Times, March 12, 2004, accessed June 14, 2017, http://www.nytimes.com/2004/03/12/sports/tv-sports-jack-lalanne-is-back-sort-of-helping-viewers-feel-guiltyagain.html.

133. “The Jack LaLanne Show Volume I," Shop LaLanne, accessed June 14, 2017, https://shoplalanne.com/products/the-jack-lalanne-show-vol1.

134. "LaLanne, Jack, 1914-2011," UCLA Library Catalogue, accessed August 13, 2017, http://cinema.library.ucla.edu/vwebv/search? searchType $=7 \&$ searchId $=154 \&$ maxResultsPerPage $=50 \&$ recCount $=50$ \&recPointer $=0$ \& resultPointer $=0$ \&headingId $=115893$.

135. “The Bonnie Prudden show. [1961-06-09]," UCLA Library Catalogue, accessed May 28, 2017, $\mathrm{http}: / /$ cinema.library.ucla.edu/vwebv/holdingsInfo?bibId=9714.

136. David Bianculli, "Bye to Treasure Trove of Old Shows," Daily News (New York, NY), June 30, 1995. Gallen's current endeavour is TVDays.com, which sells stock footage. Gallen has uploaded one episode of Drake's show to YouTube: "THE DEBBIE DRAKE SHOW CLASSIC TV SHOWS \& COMMERCIALS on DVD at TVDAYS.com," published by tvdays, November 12, 2008, accessed August 13, 2017, https://www.youtube.com/watch?v=SsoXBroVIBI. 


\section{Sculpting with the Stars}

Acceptance of exercise as a means to attain health rose considerably in the 1970 s, ${ }^{137}$ and the new home-viewing technology of video expanded the possibilities of home-based fitness. As an extension of the television screen, videocassette recorders solved many of the issues that made TV unsatisfactory for fitness purposes, enabling viewers to record, rewind, fast-forward and replay their favourite programs at any time of day. Video exponentially increased the variety of workout offerings, and along with the treadmill and a set of dumbbells, the VCR became a necessary piece of at-home fitness equipment.

Released on both VHS and laserdisc, Aerobicise ${ }^{138}$ was the first exercise release to place on Billboard's "Videocassette Top 40," peaking at number seven on 12 June 1982. ${ }^{139}$ Equal parts Busby Berkeley musical and softcore pornography, Aerobicise featured svelte women in high-cut leotards kicking and tossing their hair to a pulsating synth beat on a rotating platform (figs. 1518). Directed by erotic photographer Ron Harris, Aerobicise was shot on video with four cameras: straight on at knee-level, from a low angle at the base of the platform, at 75 degrees from the front, and from an extreme high angle, directly overhead. ${ }^{140}$ The women were usually framed in sexually-suggestive, fragmenting close-ups and/or kaleidoscopic superimposition. For this reason, "the Aerobicise video has questionable educational value," according to video artist and Hard Stars ${ }^{141}$ creator Aaron Valdez. "Ron Harris seemed more interested in filming the female body than giving the video instructional value. ... At some point he made a totally nude

137. Kolata, 57.

138. Aerobicise, directed by Ron Harris (Hollywood, CA: Tantra Productions Inc./Paramount Home Video, 1981), videocassette.

139. "Videocassette Top 40," Billboard Magazine, June 1982, 75. The Videocassette Top 40 was established in 1979, and listed the "best selling videocassettes compiled from retail sales, including releases in both Beta \& VHS formats." Video Aerobics (1979) preceded Aerobicise and was likely the first workout offering available on home video, distributed on CEDs.

140. "BESTOF:Behind the Scenes Aerobicise," YouTube, published by Ron Harris, March 19, 2015, accessed May 5, 2017, https://www.youtube.com/watch?v=gS8K0JSmq34.

141. "Hard Stars," YouTube, accessed May 5, 2017, https://www.youtube.com/user/resetcounter/. 
version. I guess it gets overlooked for these reasons." ${ }^{\prime 42}$ It was turned into a slightly more instructive cable television series, :20 Minute Workout, in 1983.
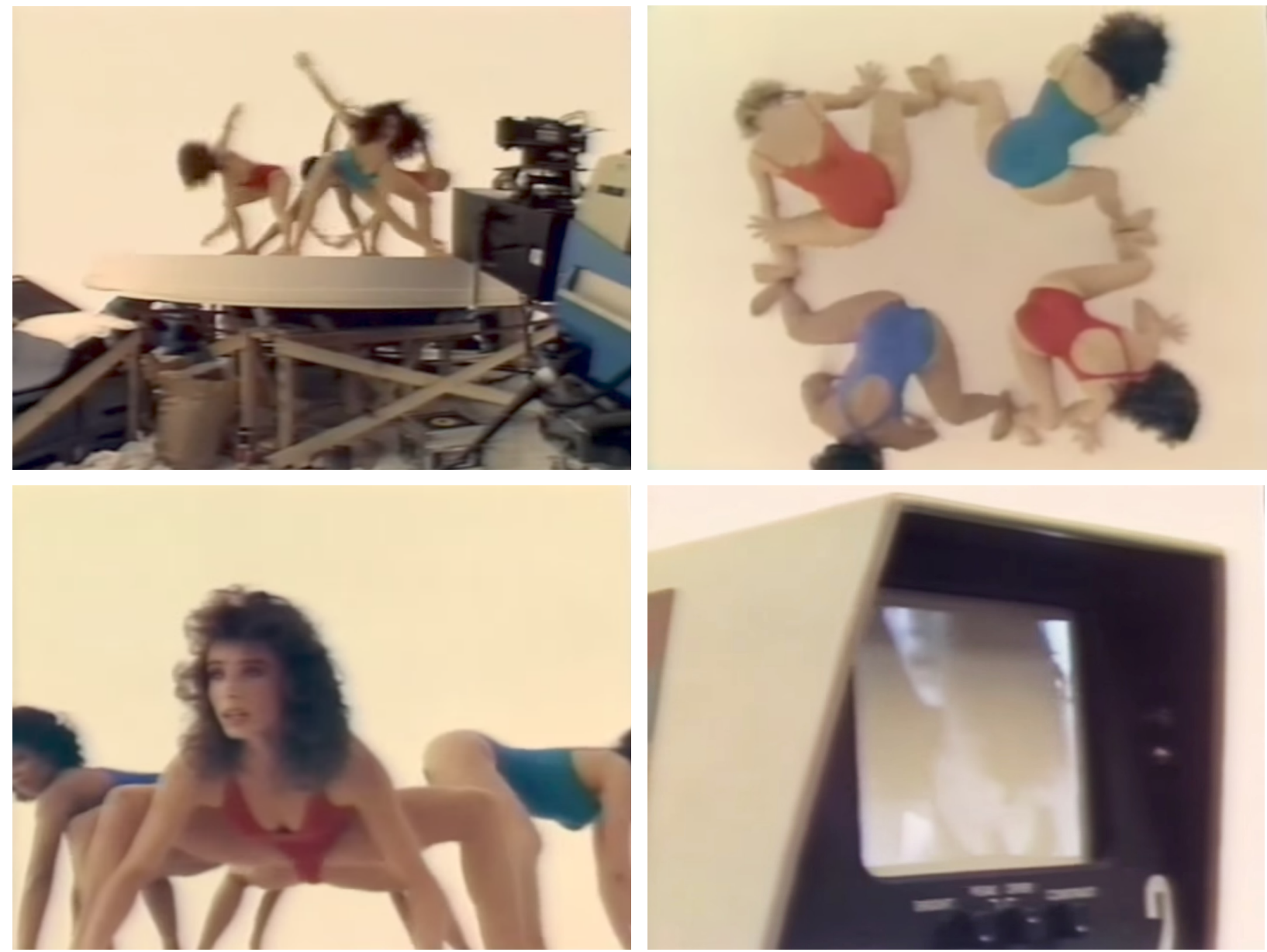

Figures 15-18. Stills from a behind-the-scenes featurette about the making of Aerobicise (1981). The performers were shot from multiple angles while exercising on a rotating platform (top left).

Source: "BESTOF:Behind the Scenes Aerobicise," YouTube, posted by Ron Harris, March 19, 2015, https://www.youtube.com/watch?v=gS8K0JSmq34.

Although Aerobicise had been on the Billboard "Top 40" for eight weeks when The Jane Fonda Workout ${ }^{143}$ entered, the former faded within the year. While it was not the first workout video, actress and political activist Jane Fonda's tape was "arguably the first production—and certainly the most famous one - that anticipated a far wider market penetration for home video,"

142. Aaron Valdez, e-mail message to author, March 1, 2017.

143. The Jane Fonda Workout, directed by Sidney Galanty (Santa Monica, CA: Karl Video Corporation, 1982), videocassette. 
according to moving image archivist and scholar Snowden Becker. ${ }^{144}$ When Workout reached number one on the Billboard chart on 2 October 1982, it was the first non-theatrical release to hold that position since the chart's inception in November 1979, causing Billboard reporter Paul Grein to wisely predict of Fonda, "the lady may wind up as the Lucille Ball of the new technology." "145 Before being kicked off its perch by Star Trek II: Wrath of Khan on 11 December, Workout had spent twenty-nine weeks on the "Videocassette Top 40" chart, nine straight at number one. In addition, over eighty thousand copies of Workout were sold on Capacitance Electronic Discs (CEDs), a quickly-discontinued videodisk format by RCA. ${ }^{146}$ According to Fonda, the video sold seventeen million copies worldwide, with all of her profits going towards the California Campaign for Economic Democracy, which she founded with her then-husband Tom Hayden. ${ }^{147}$

The huge rental and sales figures for Workout can partially be attributed to Fonda's celebrity status, but a number of factors had to converge for the video to become such a cultural phenomenon. As Billboard pointed out in 1986, "personality and credibility are clearly key factors in the genre's success." "148 Fonda had previously established herself as knowledgeable and trustworthy on the subject: after an injury, she opened and taught classes at her own exercise studio in Beverly Hills starting in 1979, and she had released both a top-selling exercise book (1981) and record (1982) before her first video. Workout's immense popularity can also be linked to the fact that it was, in Becker's words, "created to take full advantage of the unique affordances of video playback, including the potential for unlimited repeated viewings in the

144. Snowden Becker, "Suggestion for NFR," e-mail message to a member of the National Film Preservation Board, September 23, 2013; forwarded to author, February 13, 2017.

145. Paul Grein, "Chartbeat," Billboard Magazine, October 1982, 6.

146. Jim McCullaugh, "Jane Fonda's Video Victory," Billboard Magazine, August 1985, F-15. 147. Jane Fonda, "30TH ANNIVERSARY OF MY FIRST WORKOUT VIDEO," Jane Fonda Official Web Site \& Community, paragraph 3, April 24, 2012, accessed April 11, 2017, https://www.janefonda.com/30thanniversary-of-my-first-workout-video/.

148. "Exercise," Billboard Magazine April 1986, V-4. 
comfort and privacy of one's living room." ${ }^{, 149}$ For this, Fonda was called the "originator of the exercise video" format when she was awarded the Video Software Dealers' Association "Visionary Award." ${ }^{50}$ Mark Galanty—who worked on the Fonda videos with his father, director Sidney Galanty—claims that "no previous film, video or television was used as a precursor," and describes the motivation for the ninety-minute video's style:

Since no 'made for home video' exercise product was ever made before, the production design was based on the concept that, (1) audience needed to be able to follow along and not be injured, (2) the video must last repetitive use. Not too many words, not boring to watch, and could be enjoyable watching it as a exercise routine, and/or just for viewer entertainment since it was a new medium that allowed the viewer to watch over and over again, rewind, fast forward, etc. ${ }^{151}$

Workout signaled the beginning of a new mode of media consumption. ${ }^{152}$ While renting both videos and VCRs had been common practice in the early days of the technology, exercise videos gave Americans a reason to purchase their own machine and tapes. As described by video marketer Denny Kopels in 1986, "what good is renting an exercise tape going to do? You're not going to see any fitness benefits from renting it for just one or two days." ${ }^{153}$ When video players were introduced for domestic sale in 1976 , the average machine cost between $\$ 1000$ and $\$ 1400$ USD ( $\$ 4528-\$ 6340$ in 2017); by 1985, the price had plummeted and VCRs were "within the means of the masses, ${ }^{, 154}$ with most models selling for between $\$ 200$ and $\$ 400$ (\$453-\$906 in 2017) ${ }^{155}$ Some executives in the industry attributed the price drop to the emergence of South Korea as a supplier (causing Japanese and American manufacturers to lower their prices so as to

149. Becker, "Suggestion for NFR."

150. Cited in MacNeill, 165.

151. Mark Galanty, e-mail message to author, March 4, 2017.

152. Becker, "Suggestion for NFR."

153. Denny Kopels, cited by "Exercise," Billboard Magazine, April 1986, V-4.

154. Miguel Diaz, cited by Johnnie L. Roberts, "The VCR Boom: Prices Drop as Their Popularity Continues to Grow," Wall Street Journal, reprinted in Chicago Tribune, September 22, 1985, accessed April 11, 2017, http://articles.chicagotribune.com/1985-09-22/news/8503040687_1_vcr-boom-suppliers-marketers.

155. Roberts, "The VCR Boom." 
not allow South Korean models to "come into the market and sweep the mid-to-low-end prices"). ${ }^{156}$ Many (including Jane Fonda herself), however, attribute the surge in demand for the equipment, and subsequent price drop, to the popularity of The Jane Fonda Workout. In her 2005 autobiography, Fonda wrote, "[Workout $]$ helped create the home video industry. Up until then people weren't buying videos, because they didn't own the necessary hardware - a VCR player, which was expensive - and there weren't any videos that people felt they had to have for repeat use that would justify the cost of the hardware." ${ }^{157}$ By 1992, over $75 \%$ of North American households owned a video recorder. ${ }^{158}$

With the majority of American women working in the public sphere for the first time in U.S. history, definitions of femininity were shifting rapidly during the 1980 s and women became the prime targets for fitness video advertising. ${ }^{159}$ Packaging frequently implored consumers to "sculpt," "tone," and "firm" their bodies, to "burn fat!" and "shape up!" while they "exercise with the stars." Fonda used the rhetoric of empowerment, arguing that video had the power to democratize fitness and make self-transformation accessible to working women. In the cover story for Billboard's August 1985 issue on “Jane Fonda's Video Victory,” Fonda expressed that she felt her videos were "well-suited to professional woman homemakers... busy women who would find it difficult to get to a studio. The only way they could exercise is if they could do it at home." ${ }^{160}$ Workout tapes gave women with little experience with exercise or time for self-care an introduction to the world of physical culture. Even at the lofty suggested retail price of $\$ 39.95$ (\$100 in 2017), Fonda’s video granted access to high-quality physical instruction to those who

156. Donald F. Johnstone, cited by Roberts, "The VCR Boom."

157. Jane Fonda, My Life So Far (New York: Random House, 2005), 394; cited by Steven Boyer, "Jane Fonda's Wii Fit: Continuity, Contingency, and Concordance in Fitness Gaming," (paper presented at Digital Games Research Association DiGRA Conference, 2011).

158. Hilderbrand, Inherent Vice, 248.

159. Radner, 110.

160. Cited in McCullaugh, "Video Victory," F-3. 
could not afford more individualized guidance such as from a personal trainer.
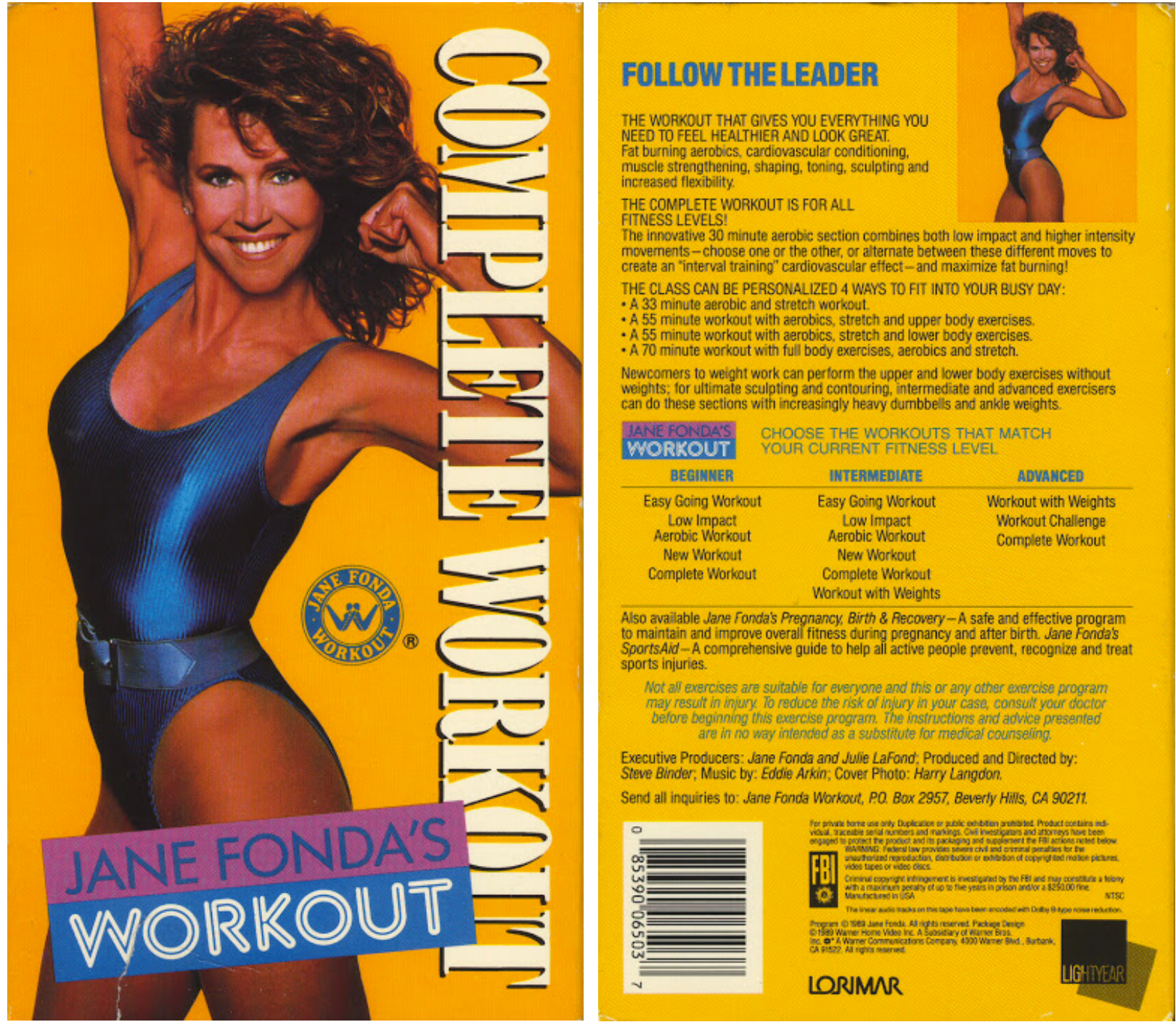

Figure 19. Front (left) and back (right) cover of a used VHS copy of Jane Fonda's Complete Workout (1989). Source: Package design (C) Warner Home Video Inc. 1989. Digitized by Aaron Valdez.

While Fonda tends to overshadow them, a wide range of actors, athletes and modelsfrom Debbie Reynolds ${ }^{161}$ to O.J. Simpson ${ }^{162}$ — capitalized on the trend, producing hundreds of videos that would help define the body ideals, fashions, aesthetics and gender roles of the ' 80 s.

Videos were made for seemingly every demographic, including men, pregnant women, children,

161. Do It Debbie's Way, directed by Kevin Carlisle (Hollywood, CA: Raymax Productions, Inc. and Paul Brownstein Productions Inc., 1984), videocassette.

162. O.J. Simpson Minimum Maintenance Fitness for Men, directed by Nancy DiToro (Beverly Hills, CA: Alta Loma Productions, Inc., 1994), videocassette. 
and those with limited mobility. By 1986, producers were targeting particular body parts; Kopels observed, "I see exercise videos getting more specific, such as our 'Say Goodbye To Back Pain' tape. Because I think the exercise market is pretty flooded at this point, and even the personality aspect has reached saturation." ${ }^{163}$ As many as five-hundred fitness videos were being produced per year in the late 1980 s and early ' 90 s; ${ }^{164}$ Fonda alone would go on to make twenty-one more fitness videos by 1995 .

The mass production of workout tapes can partially be attributed to the affordability of the video format. Video technologies were changing rapidly in the 1980s, with new formats developed every couple of years. According to Galanty, the first Fonda videos were shot on 1" tape with a $3 / 4$ " video simulcast recording used for off-line editing; they later switched to the D2 format and then Digital Betacam. The videos were shot in a three-camera system, "much like a live television production," with a control room live edit recorded at the time of production. He elaborated on the rationale for the decision to shoot on video:

We sometimes needed to take a section of one take and insert that exercise movement into another take. Film would have been a very expensive and difficult medium to use for this product. In addition, when down-converting from negative to video, the quality of image would have made it so the average viewer could not know the difference. Our [director of photography], Brian Reynolds, was talented at making video look like film. Most editors could not tell us if we shot on film or video in post unless we told them. ${ }^{165}$

The cheaper medium came with the drawback of being a less reliable format for preservation. While film can remain stable for more than a hundred years if stored at optimal temperature and humidity, magnetic tape formats can be classified as 'deteriorating' from the moment they are made. ${ }^{166}$ Videotape can be expected to last closer to thirty years, ${ }^{167}$ meaning the

163. "Exercise," Billboard Magazine April 1986, V-4.

164. Jill Ross, cited by Losano and Risch, 113.

165. Galanty, e-mail message to author, March 1, 2017.

166. Howard Besser, Melissa Brown, Robert Clarida, Walter Forsberg, Mark Righter and Michael Stoller, 
exercise videos of the " 80 s and ' 90 s may be reaching the end of their playable life. Primarily due to equipment obsolescence, "sticky-shed syndrome," loss of lubricant and demagnetization, video has proven to have inherent vices that make it inappropriate for long-term archiving. ${ }^{168}$ For this reason, Galanty says, Warner Brothers made negative film prints of the Workout video "because they weren't sure how long the video or digital would last." 169

With video tapes rapidly degrading and no professional-grade VCRs currently being manufactured (making the VHS format obsolete), ${ }^{170}$ distributors are now re-releasing some of these videos on DVD, which largely supplanted VHS by 2000. Lightyear Entertainment, an original co-producer of the Fonda series, "remastered" Fonda's tapes for DVD in 2014. In an interview with Shape Magazine, Fonda explained the demand: "I cannot tell you the number of people over the years that have written to me. Hundreds of people have lost the VHS, it tore, it ripped, someone borrowed it and didn't return it, people don't have VCR players anymore... all kinds of reasons." ${ }^{171}$ Lightyear CEO Arnie Holland says "sales have been excellent; people wanted them. Not like in the '80s and '90s, but still, sales exceeded expectations." He elaborated on the "remastering" process for Workout:

After pulling digital files from the master tapes, we found they needed work. Modern TVs and DVD players are so much sharper than they were. Having been involved with Jane from the very beginning in 1982, when I was a VP at RCA, I was shocked by how they looked on a modern TV. We had the most persnickety technical team in the business at RCA. Anything not up to snuff would have been rejected. Those programs looked fine

Video at Risk: Preserving Commercial Video Collections in Research Libraries (New York: NYU Libraries, 2012), 6.

167. John W. C. Van Bogart, Magnetic Tape Storage and Handling: A Guide for Libraries and Archives (Washington, DC: The Commission on Preservation and Access and St. Paul, MN: National Media Laboratory, 1995), 15.

168. "Sticky shed" occurs when the tape binder absorbs moisture, causing both the binder and the magnetic particles to detach during playback. Mona Jimenez and Liss Platt, Videotape Identification and Assessment Guide (Austin, TX: Texas Commission on the Arts, 2004), 37.

169. Galanty, e-mail message to author, March 1, 2017.

170. Besser et al., 8 .

171. Sarah Angle, “Jane Fonda's Workout Videos to Be Released on DVD," Shape Magazine, December 29, 2014, accessed March 4, 2017, http://www.shape.com/fitness/trends/jane-fondas-workout-videos-be-releaseddvd. 
on '80s TVs. But they didn't look so great now. Was that deterioration? Or was it the new TVs? We were never totally sure, but I think it's just the current TV standards. Either way, we had to engage in extensive color correction. Played with the color saturation as well. At times we were choosing between making faces look right and making clothing look right. ${ }^{172}$

Digitized versions of lesser-known workout videos are frequently shared through online platforms. For example, the Internet Archive hosts many (mostly amateur) workout videos, and in 2011 Aaron Valdez created the YouTube channel Hard Stars, which now features "the most comprehensive collection of celebrity workout videos on VHS in the world." ${ }^{\prime 73}$ Valdez-a selfdescribed "long-time purveyor of horrible instructional VHS" - has uploaded hundreds of exercise videos, mostly excerpts of longer videos from the 1980s and ' $90 \mathrm{~s}$, and explains that many of them have achieved "cult status." The most popular videos have an abundance of camp value — exaggerated, frivolous, outdated, artificial ${ }^{174}$ — with viewers likely drawn to them out of a combination of irony and nostalgia.

Many of the videos produced during this era can be considered "orphans," moving images that have been 'abandoned' by their copyright holders or have unlocatable copyright holders. ${ }^{175}$ According to Valdez, "many videos were one-offs and there's no information readily available about them,"176 including information about copyright holders. Orphan films and videos are particularly vulnerable to neglect and degradation, as there is no responsible party to cover the expenses of preservation (which can be considerable). When asked about whether original producers or distributors ever contact him about copyright infringement, Valdez said,

172. Arnie Holland, e-mail to author, May 16, 2017.

173. Valdez, “About," Aaron Valdez, accessed May 5, 2017, http://www.aaronvaldez.com/about/.

174. Susan Sontag, "Notes on Camp" in Against Interpretation and Other Essays (New York: Farrer Straus \& Giroux, 1964). (2007), 125 .

175. Dan Streible, "The Role of Orphan Films in the 21 st Century Archive," Cinema Journal 46, no. 3,

176. Valdez, e-mail message to author, March 1, 2017. 
You can tell by [how few distributors have contacted him] that not many care about their videos. Most monetization is happening through automated audio Content ID matches from the music industry, not distributors searching their back catalogs. I actually get a lot of requests to upload full versions or sell digital copies because people are attached to certain videos. There's certainly money to be made but I guess it's not enough money. ${ }^{177}$

Digital objects have their own complex set of preservation concerns. While the present study ends in the 1980s, digital technologies have made producing, distributing and watching content continuously cheaper and easier, and the production of home exercise media has remained strong into the 2010 s. Celebrities and trainers continue to release new fitness routines on DVD, and amateurs upload their own versions to streaming sites like YouTube. Exercise media is also becoming more interactive: for example, Nintendo's Wii Fit offers evaluative and responsive exercise video games, and smartphones can be loaded with instructional fitness "apps" that can coach you through yoga or a quick workout using much of the same rhetoric and stylistic techniques of the films and videos that came before them. While this latest batch of home fitness media falls outside the scope of this project, the way they are used is worthy of future research, assuming they are preserved long enough to be studied.

177. Ibid. 


\section{Conclusion}

Home fitness routines have been recorded and collected on a variety of home-viewing formats for nearly one-hundred years, but from the "splendid movements" of Pathex's threeminute reels in 1926 to Angela Lansbury's Positive Moves in 1988, this genre is frequently omitted from media histories and neglected by traditional cultural heritage institutions. Exercise media provides cultural insight into twentieth century conceptions of the body, celebrity, consumerism and non-theatrical viewing practices, but its reputation as mass-produced, nontheatrical, apolitical and "excessively carnal"" makes it a low priority for collecting institutions. While long-ingrained institutional taste biases_favouring the exclusive over the popular ${ }^{179}$ and the cerebral over the bodily ${ }^{180}$ — are at least partially to blame for the genre's exclusion, the formats on which these media have been disseminated are another clear reason why this genre has been neglected. This conclusion will outline recommendations for ways in which both institutions and individuals can help extend the lifelines of these cultural objects.

One concrete step towards better providing greater access to these materials would be to formally recognize instructional exercise programs as their own genre for cataloguing purposes. ${ }^{181}$ Genre is described by the Library of Congress as the "single best recognized and intrinsically appropriate way to categorize film and television works into readily understood classifications," 182 yet despite thousands of examples of this very distinct genre, there is

178. Hilderbrand, "Sweatin' Out the Shame," paragraph 2.

179. Andrew Bottomley, "Silenced Sounds: The State of Post-1940 Popular Music in United States Libraries and Archives," Journal of Popular Music Studies 28, no. 2 (2016), 240. Bottomley points out that these biases are "distinctly classed, gendered, and raced."

180. See: Carol J. Clover, "Her Body, Himself: Gender in the Slasher Film," Representations 20 (1987), 187-228; Linda Williams, "Film Bodies: Gender, Genre, and Excess," Film Quarterly 44, no. 4 (1991), 3.

181. Genre is defined by Library of Congress as "categories of works that are characterized by similar plots, themes, settings, situations, and characters." Library of Congress, "Frequently Asked Questions about Library of Congress Genre/Form Terms for Library and Archival Materials," last modified 2011, accessed June 5, 2017, http://www.loc.gov/catdir/cpso/genre_form_faq.pdf.

182. Brian Taves, Judi Hoffman, and Karen Lund, "Introduction," The Moving Image-Form Guide, last 
currently no Genre/Form Heading for exercise media recognized by LC's Moving Image GenreForm Guide. ${ }^{183}$ Instead, The Jane Fonda Workout is listed as an example of the "instructional film" genre, broadly defined as "nonfiction work designed to impart skills or techniques to general audiences, typically in a 'how-to' manner." ${ }^{\text {81 }}$ While this is technically accurate, it lacks sufficient specificity, which can make discovering these films and videos difficult and lead to mis-cataloguing. Given the ubiquity of this kind of moving image, acknowledging exercise films as a sub-category of instructional film would help legitimize the genre, make these titles more discoverable, and help researchers make connections.

Genre and format are intimately entwined. The most popular domestic formats, television and analogue video, are particularly vulnerable media, and the format hierarchies of film preservation may be impeding the survival of many of these works. While the inherent instability of film materials has been well publicized thanks to institutions such as the National Film Preservation Fund and the National Film Registry, ${ }^{185}$ media that was originally shot on video may be even more vulnerable, yet it receives far less funding for preservation. Archivist Margaret A. Compton calls television "one of our most fragile cultural assets" due to a lack of preservation funds, material instabilities and equipment obsolescence. ${ }^{186}$ There is also a cultural and institutional bias towards film over video; while it is true that film can capture a higherdefinition image than video can, both the content and aesthetics of images captured on video are worth preserving. More even distribution of media preservation grants between film, television

modified February 1998, accessed June 5, 2017, https://www.loc.gov/rr/mopic/migintro.html\#intro.

183. Taves, Hoffman, and Lund, The Moving Image Genre-Form Guide, accessed June 5, 2017, https://www.loc.gov/rr/mopic/miggen.html.

184. Taves, Hoffman, and Lund, "Instructional," Moving Image Genre List, accessed June 5, 2017, https://www.loc.gov/rr/mopic/miggen.html\#Instructional.

185. With the help of public ballots, the National Film Preservation Board selects up to 25 films each year to be preserved by the Library of Congress, based on the films' subjective "cultural, historical, or aesthetic significance." Library of Congress, "Nominate," National Film Registry, accessed April 25, 2017, https://www.loc.gov/programs/national-film-preservation-board/film-registry/nominate/.

186. Compton, 130. 
and video archiving would undoubtedly benefit this genre.

While institutions such as the Paley Center for Media and the Museum of the Moving Image do important work to preserve these non-theatrical genres and non-film formats, creating National Television and Video Registries at the Library of Congress would be another small step towards elevating the status of works that are not eligible for the National Film Registry. UCLA's Snowden Becker has advocated for the inclusion of The Jane Fonda Workout in the National Film Registry for years, arguing that Workout is not only demonstrably culturally and historically significant, but also aesthetically ground-breaking, having set an "enormously influential visual standard for instructional media." ${ }^{, 187}$ Having not originated on film, however, it is ineligible for the NFR. As a response, she suggested a new campaign for the creation of a National Video Registry to the Association of Moving Image Archivists:

Registry criteria already state that works must be at least 10 years old to be considered, and that means we're quickly moving toward a moment when the majority of the commercial feature film output of the U.S. - long a mainstay of the Registry - will be ineligible under the "originated on film" criteria. The [National Film Preservation Board]'s mandate includes "apprising the Librarian [of Congress] of changing trends and policies in the field of film preservation," and also works to "ensure the survival, conservation, and increased public availability of America's film heritage." Acknowledgement of the fact that video-original materials are at considerable risk, and that these works make unique and important contributions to the range and diversity of our motion picture heritage, is long past due. ${ }^{188}$

Although there has been a recent surge in interest in marginal works and ongoing efforts to "save" orphan films, exercise media are rarely cited as examples of moving images in need of protection. As discussed in Chapter 5, many workout videos meet the strict legal definition of "orphan;" most fitness media also meet the broad intellectual definition put forth by orphan films advocate Dan Streible: "all types of neglected cinema," whether it be physical, commercial,

187. Becker, "Suggestion for NFR."

188. Becker, "On the possibility of an all-video NFR in 2017," e-mail message to AMIA listserv, February $10,2017$. 
cultural and/or historical. ${ }^{189}$ Exercise films, television programs and videos can specifically be viewed as "ephemeral" moving images-films "not identified by creators or recognized collecting repositories as having continuing value beyond an initial function" ${ }^{, 190}$-as they are frequently outdated and lack programming potential, being repetitive and non-narrative. Home exercise films deserve to be part of the orphan films preservation push, as these films and videos lack many of the traditional markers of cultural importance (as art and/or historical record) that archives are usually interested in collecting, but undoubtedly have historical value that make them worth saving.

Given the volume of output of this genre, it cannot be reasonably expected that it will all be professionally preserved. The continued availability of many examples of home exercise media is largely thanks to a number of individual enthusiasts rather than any sort of collective effort by cultural heritage institutions. While there is legitimacy in the institution of the archive, many of these videos live on through alternative forms of access and preservation, and the decentralized amateur archiving of Jerry Wagner, Ira Gallen, Aaron Valdez and others should be enabled and recognized. Although privately-held material has traditionally been difficult for scholars to access, collector- and community-based archives are increasingly accessible and discoverable to the public. As long as mass culture is not widely regarded as something worth preserving for the long term, ${ }^{191}$ home exercise media will be largely dependent on private collectors to ensure their preservation.

189. Dan Streible, "The State of Orphan Films," The Moving Image 9, no. 1 (2009): x. 190. Timothy Wisniewski, "Framers of the Kept: Against the Grain Appraisal of Ephemeral Moving Images," The Moving Image 7, no. 2 (2007), 13.

191. Bottomley, 240. 


\section{Appendix A}

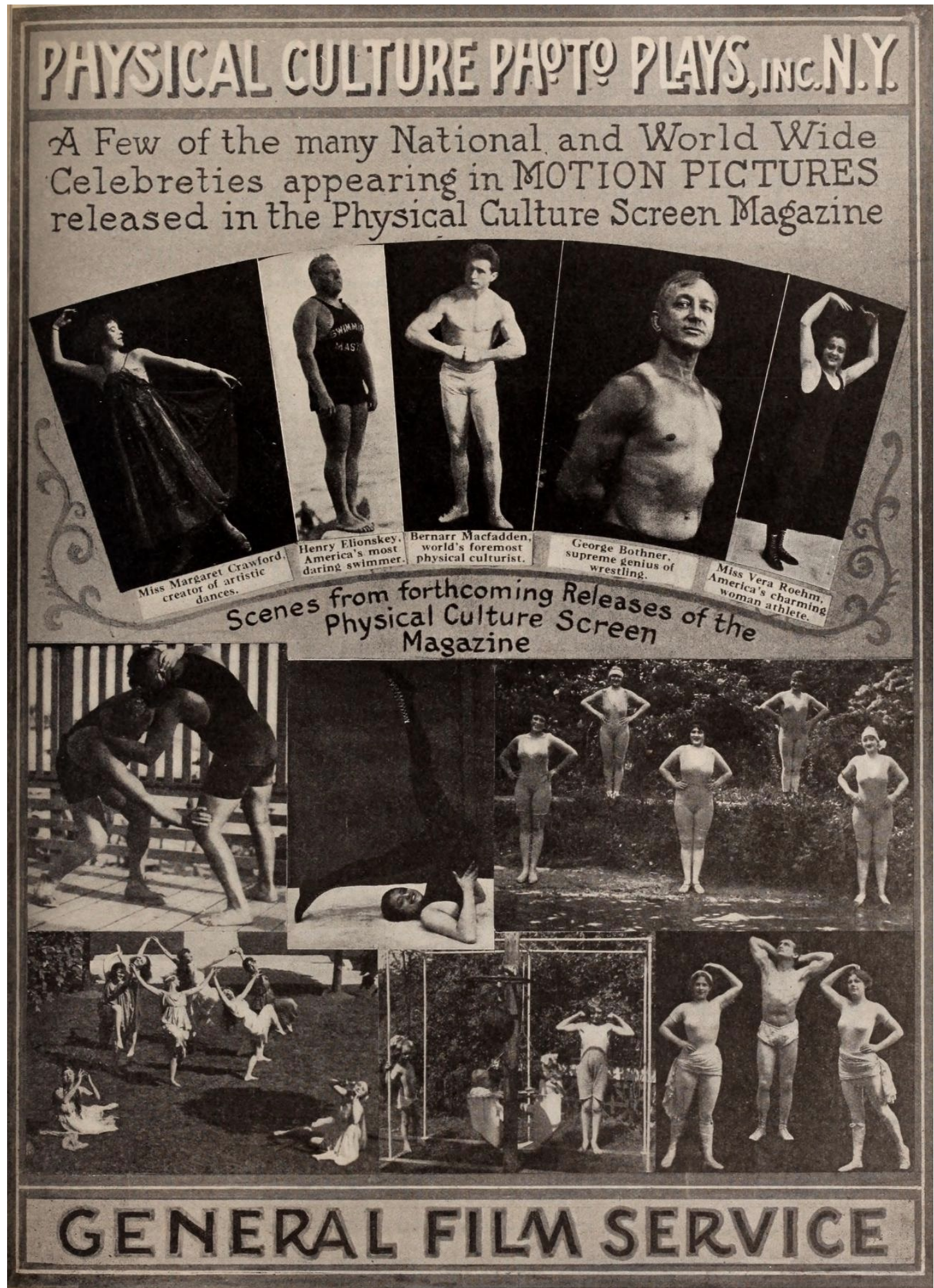

Advertisement for Bernarr Macfadden's Physical Culture Photo Plays Inc. from 1917.

Source: Motion Picture News (December 1917), 3755. Digitized by the Media History Digital Library, http://archive.org/stream/motionpicturenew16moti_1\#page/3754/. 


\section{Appendix B}

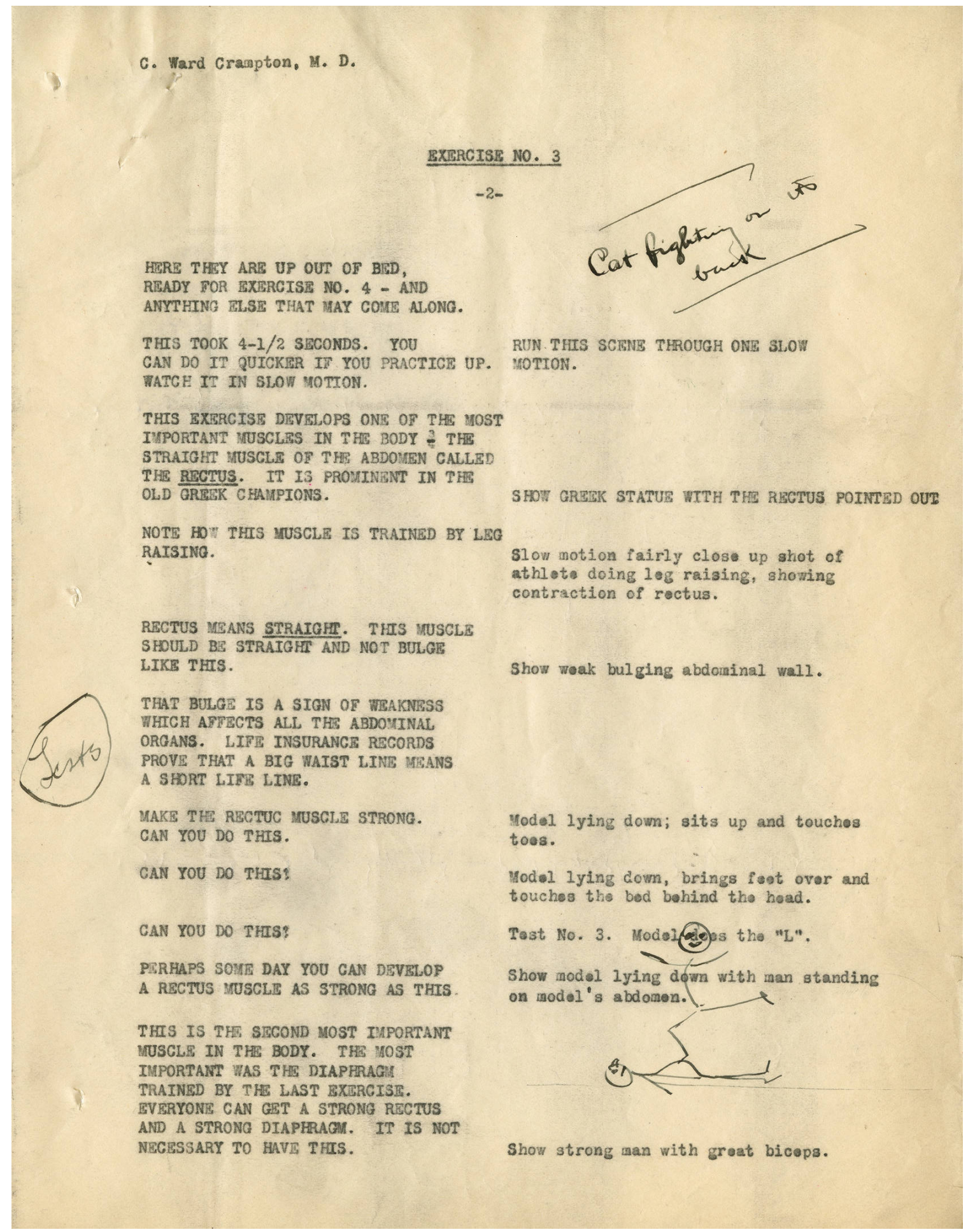

A page from C. Ward Crampton's 1924 film script, detailing "Exercise No. 3."

Source: C. Ward Crampton, "Script for film on Physical Culture Series" (manuscript), C. Ward Crampton Papers (series 3, box \#5, folder \#7), 11. Courtesy of Springfield College, Babson Library, Archives and Special Collections. Digitized by Springfield College Digital Collections, http://cdm16122.contentdm.oclc.org/cdm/compoundobject/collection/p15370coll2/id/17483/rec/5. 


\section{Appendix C}

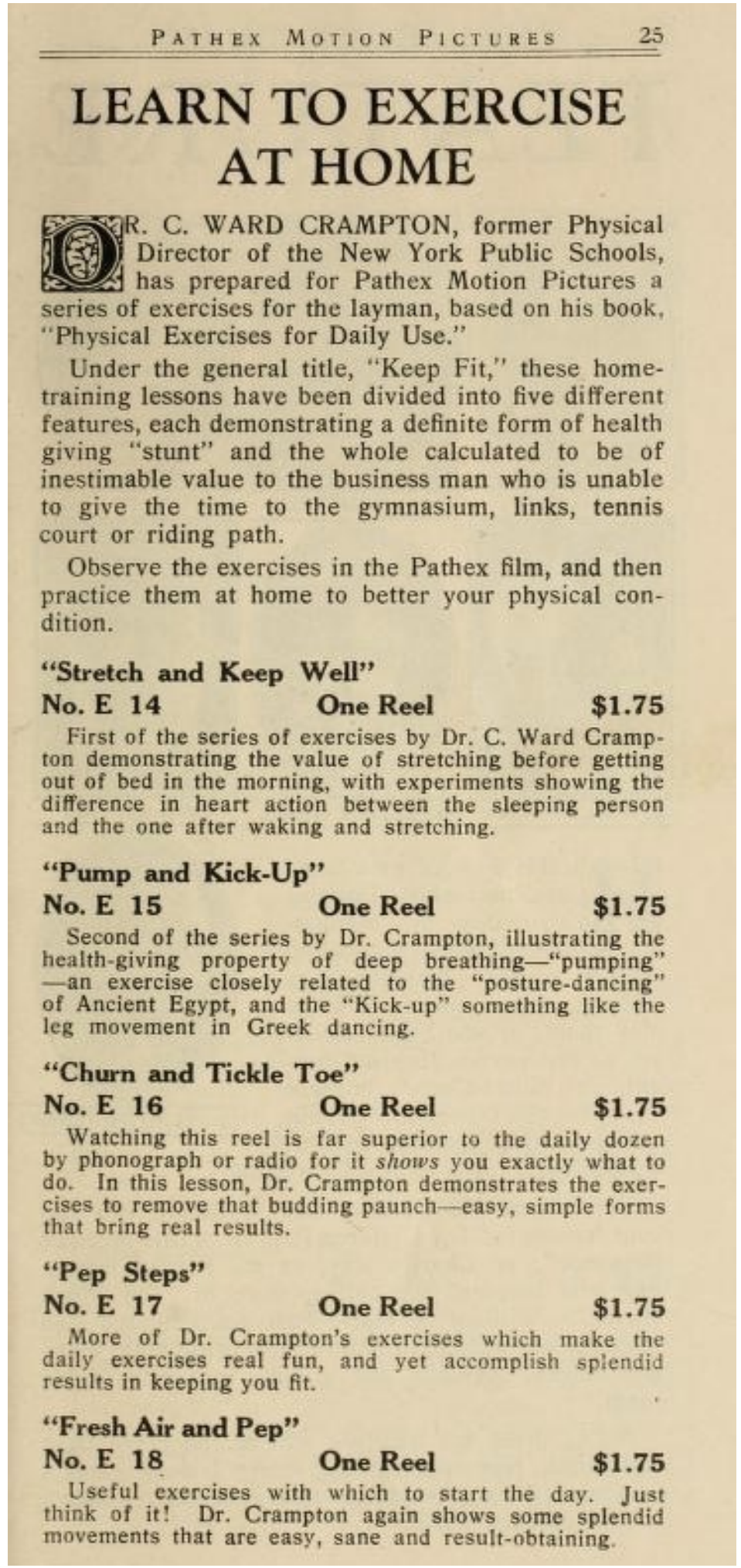

Description of the "Keep Fit" series in the 1926 catalogue of Pathex Motion Pictures for the Home.

Source: Pathé Exchange, Inc., Pathex Motion Pictures for the Home (1926), 25. Digitized by the Media History Digital Library, http://archive.org/stream/catalogofpathexm1926path\#page/24/. 


\section{Bibliography}

“7 Health Pictures Ready for Release." Variety, July 1924: 17. Media History Digital Library. http://archive.org/stream/variety75-1924-07\#page/n63/.

Acland, Charles R. and Haidee Wasson, eds. Useful Cinema. Durham: Duke University Press, 2011.

“Among the Magazines.” The Educational Screen. September 1924: 271. Media History Digital Library. http://archive.org/stream/educationalscree03chicrich\#page/n275/.

Angle, Sarah. "Jane Fonda's Workout Videos to Be Released on DVD." Shape Magazine, December 29, 2014, accessed March 4, 2017. http://www.shape.com/fitness/trends/janefondas-workout-videos-be-released-dvd.

Battan, Carrie. "Thank You, Jane Fonda: A Brief History of America's Obsession with Workout Videos." Grantland, April 14, 2015. http:/grantland.com/hollywood-prospectus/ thank-you-jane-fonda-a-brief-history-of-americas-obsession-with-workout-videos/.

Besser, Howard, Melissa Brown, Robert Clarida, Walter Forsberg, Mark Righter, and Michael Stoller. Video at Risk: Preserving Commercial Video Collections in Research Libraries. New York: NYU Libraries, 2012. http://guides.nyu.edu/ld.php?content_id=24818036.

Bianculli, David. "Bye to Treasure Trove of Old Shows." Daily News (New York, NY), June 30, 1995. TVDays. https://www.tvdays.com/reviews.

Black, Jonathan. Making the American Body: The Remarkable Saga of the Men and Women Whose Feats, Feuds, and Passions Shaped Fitness History. Omaha, NE: University of Nebraska Press, 2013.

Bornouw, Eric. A Tower in Babel: A History of Broadcasting in the United States to 1933. New York: Oxford University Press, 1966.

Bottomley, Andrew. "Silenced Sounds: The State of Post-1940 Popular Music in United States Libraries and Archives." Journal of Popular Music Studies 28, no. 2 (2016): 224-47.

Boyer, Steven. “Jane Fonda's Wii Fit: Continuity, Contingency, and Concordance in Fitness Gaming.” Presented at Digital Games Research Association DiGRA Conference, 2011.

Braun, Marta. Picturing Time: The Work of Etienne-Jules Marey (1830-1904). Chicago, IL: University of Chicago Press, 1994.

"Building Up the Health of the Nation." Motion Picture News, January 1916: 528. Media History Digital Library. http://archive.org/stream/motionpicturenew131unse\#page/528/. 
“C. Ward Crampton Papers, Series 3 (Personal Papers).” Box \#5, folder \#7, Archives and Special Collections, Springfield College, Springfield, MA.

Clark, June. "New Shape-Up.” Radio TV Mirror, September 1961: 30-31. Media History Digital Library. http://archive.org/stream/radiotvmir00ma\#page/n247/.

Clover, Carol J. "Her Body, Himself: Gender in the Slasher Film.” Representations 20 (Fall 1987): 187-228.

Compton, Margaret A. "The Archivist, the Scholar, and Access to Historic Television Materials." Cinema Journal 46, no. 3 (2007): 129-133.

Crampton, C. Ward. Physical Exercise for Daily Use. New York \& London: G.P. Putnam's Sons, 1924.

Cupler, A.T. "Rural Electrification in the United States." Editorial Research Reports 1926, vol. III. Washington, DC: CQ Press, 1926. Accessed June 14, 2017. http://library.cqpress.com/cqresearcher/cqresrre1926083000.

Daoust, Phil. “A History of Fitness Fads.” The Guardian (London, UK), January 8, 2011, accessed May 16, 2017. https://www.theguardian.com/lifeandstyle/2011/jan/08/historyfitness-fads.

““Debbie Drake' Sales.” Variety, March 1962: 25. ProQuest (1032442796).

"Dr. C. Ward Crampton is Dead." New York Times, October 22, 1964. http://www.nytimes.com/1964/10/22/dr-c-ward-crampton-is-dead.html.

Ernst, Robert. Weakness is a Crime: The Life of Bernarr Macfadden. Syracuse, NY: Syracuse University Press, 1991.

“Exercise series.” Broadcasting. January 1961: 68. Media History Digital Library. http://archive.org/stream/broadcastingtele60unse\#page/n141/mode/2up

Fabian, Ann. "Making a Commodity of Truth: Speculations on the Career of Bernarr Macfadden." American Literary History 5, no. 1 (1993): 51-76.

Fitzpatrick, Shanon. "Pulp Empire: Macfadden Publications, Transnational America, and the Global Popular.” PhD diss., University of California, Irvine, 2013.

Fonda, Jane. My Life So Far. New York: Random House, 2005.

Freeman, Frank N. "Types of Educational Motion Pictures." Visual Education, September 1923: 205-. Media History Digital Library. http://archive.org/stream/visualeducation04soci\#page/n235/. 
Garelick, Rhonda. "Outrageous Dieting: The Camp Performance of Richard Simmons." Postmodern Culture 6, no. 1 (1995).

“Golden Pond Tops Vid Chart for 14th Week.” Billboard Magazine, September 1982: 29. Google Books. https://books.google.com/books?id=OyQEAAAAMBAJ

Grein, Paul. "Chartbeat.” Billboard Magazine, October 1982: 6. Google Books. https://books.google.com/books?id=giQEAAAAMBAJ.

Griffith, R. Marie. Born Again Bodies: Flesh and Sprit in American Christianity. Berkeley: University of California Press, 2004.

Hilderbrand, Lucas. Inherent Vice: Bootleg Histories of Videotape and Copyright. Durham, NC: Duke University Press, 2009.

Hilderbrand, Lucas. "Sweatin' Out the Shame.” Flow 11, no. 12 (2010). http://flowtv.org/?p=4971.

Hilmes, Michele. "The Bad Object: Television in the American Academy." Cinema Journal 45, no. 1 (2005): 111-17

Hunt, William R. Body Love: The Amazing Career of Bernarr Macfadden. Bowling Green, OH: Popular Press, 1989.

Jimenez, Mona and Liss Platt. Videotape Identification and Assessment Guide. Austin, TX: Texas Commission on the Arts, 2004. www.arts.texas.gov/wpcontent/uploads/2012/04/video.pdf.

Kagan, Elizabeth, and Margaret Morse. "The Body Electronic-Aerobic Exercise on Video: Women's Search for Empowerment and Self-Transformation." TDR 32, no. 4 (1988): 164-80.

Keightley, Keir. "Low Television, High Fidelity: Taste and the Gendering of Home Entertainment Technologies." Journal of Broadcasting \& Electronic Media 47, no. 2 (2003): 236-59.

Kolata, Gina. Ultimate Fitness: The Quest for Truth About Exercise and Health. New York: Farrar, Straus \& Giroux, 2003.

Kula, Sam. Appraising Moving Images: Assessing the Archival and Monetary Value of Film and Video Records. Lanham, MD: Scarecrow Press, 2003.

Lahue, Kalton C. Continued Next Week: A History of the Moving Picture Serial. Norman, OK: University of Oklahoma Press, 1969. 
“Local TV Program Exercises Prerogative, Gets Syndicated.” Sponsor, May 1961: 6. Media History Digital Library. http://archive.org/stream/sponsor151426spon\#page/n605/.

Macfadden, Bernarr. Superb Virility of Manhood: Giving the Causes and Simple Home Methods of Curing the Weaknesses of Men. Spotswood, NJ: Physical Culture Publishing Co., 1904. Yale University, Cushing/Whitney Medical Library. https://archive.org/details/superbvirilityof00macf.

“Macfadden Screen Magazine.” The Moving Picture World, November 1917: 1010. Media History Digital Library. http://archive.org/stream/mopict34chal\#page/1010/.

"MacFadden Tells Why He Made 'Zongar."' Motion Picture News, March 1918: 1460. Media History Digital Library. http://archive.org/stream/motionpicturenew171unse\#page/1460/.

MacNeill, Margaret. "Sex, Lies, and Videotape: The Political and Cultural Economies of Celebrity Fitness Videos." In Sport and Postmodern Times, edited by Geneviève Rail. Albany: SUNY Press, 1998.

McCullaugh, Jim. “Jane Fonda's Video Victory.” Billboard Magazine, August 1985: F-15. Google Books. https://books.google.com/books?id=yCQEAAAAMBAJ.

McCullaugh, Jim. “A Retailer's Guide to Exercise Video.” Billboard Magazine, February 1986: E-1. Google Books. https://books.google.com/books?id=wSQEAAAAMBAJ.

McKenzie, Shelly. Getting Physical: The Rise of Fitness Culture in America. Lawrence, KS: University Press of Kansas, 2013.

"Motion Picture Outfit for Home Use Placed on Market by Pathex Inc." Motion Picture News, August 1925: 1070. Media History Digital Library. http://archive.org/stream/motionpicturenew00moti_8\#page/1070/.

"National Board of Y.W.C.A. Laud 'Keep Fit.” Exhibitor's Trade Review, October 1924: 48. Media History Digital Library. http://archive.org/stream/exhi00newy\#page/n535/.

“New TV-Tape Firm.” Broadcasting, May 1959: 83. Media History Digital Library. http://archive.org/stream/broadcastingtele56unse_0\#page/n569/.

Newman, Michael Z. Video Revolutions: On the History of a Medium. New York: Columbia University Press, 2014.

"Nine Changes Ordered in 'Zongar." Motion Picture News, March 1918: 1600. Media History Digital Library. http://archive.org/stream/motionpicturenew171unse\#page/1600/.

Nineteen Twenty-Five Catalogue of Pathépictures Selected for Educational, Religious and Social Groups. New York: Pathé Exchange, Inc., 1925. Media History Digital Library. https://archive.org/details/catalogueofpathe00path. 
"Now at Last You Can Get Big Feature 'Stories' in Lengths You Can Play." The Film Daily, September 1924: iv-v. Media History Digital Library. http://archive.org/stream/filmdaily2930newy\#page/n169/.

“... Of Curves, Charts \& Debbie Drake.” Variety, June 1961: 25. ProQuest (1032432244).

Orgeron, Devin, Marsha Orgeron and Dan Streible, eds. Learning with the Lights Off: Educational Film in the United States. New York: Oxford University Press, 2011.

Overmier, Judith and Rhonda Harris Taylor. "Popular Culture in the Collection: Dancing With an Expanding Universe." Collection Building 14, no. 3 (1995): 32-37.

Overton, Rebecca. "Finding Aid: C. Ward Crampton Papers 1920-1952." Springfield, MA: Springfield College Archives and Special Collections, 2012. Springfield College Digital Collections. http://cdm16122.contentdm.oclc.org/cdm/ref/collection/p15370coll2/id/2288.

Paige, Earl. "Exercise on Threshold of Greatest Expansion." Billboard Magazine, February 1986: E-6. Google Books. https://books.google.com/books?id=wSQEAAAAMBAJ.

Pathex, Inc. Catalog of Pathex Motion Pictures for the Home. New York: Pathé Exchange, Inc., 1926. Media History Digital Library. http://archive.org/stream/catalogofpathexm1926path.

Petersen, Clarence. "How Velda Louise Bellah Became TV's Debbie Drake.” Chicago Tribune, February 15, 1970, accessed May 29, 2017. http://archives.chicagotribune.com/1970/02/ 15/page/438/article/how-velda-louise-bellah-became-tvs-debbie-drake/.

"Physical Culture Photoplays, Inc. N.Y." Motion Picture News. December 1917: 3755. Media History Digital Library. http://archive.org/stream/motionpicturenew16moti_1\#page/3754/.

Pierce, David. The Survival of American Silent Feature Films: 1912-1929. Washington, DC: Council on Library and Information Resources, 2013. https://www.clir.org/pubs/reports/pub158.

Prudden, Bonnie. “Arms, rope and a bell.” Sports Illustrated. October 1958: 56. https://www.si.com/vault/issue/41201/1/3.

Radner, Hilary. "Producing the Body: Jane Fonda and the New Public Feminine." In Constructing the New Consumer Society, edited by Pekka Sulkunen, John Holmwood, Hilary Radner, Gerhard Schulze, Jo Campling, 108-133. London: Pelgrave Macmillan, 1997. 
Roberts, Johnnie L. "The VCR Boom: Prices Drop as Their Popularity Continues to Grow." Wall Street Journal (New York, NY), September 22, 1985, accessed April 11, 2017. http://articles.chicagotribune.com/1985-09-22/news/8503040687_1_vcr-boom-suppliers -marketers.

Rossen, Jake. "How 'Jane Fonda's Workout' Conquered the World.” Mental Floss, June 19, 2015, accessed April 20, 2017. http://mentalfloss.com/article/65314/how-jane-fondasworkout-conquered-world.

Russel, Vanessa. "Make Me a Celebrity: Celebrity Exercise Videos and the Origins of Makeover Television." In Makeover Television: Realities Remodeled, edited by Dana Heller, 67-78. New York: I.B. Tauris \& Co. Ltd., 2007.

Sandomir, Richard. “TV SPORTS; Jack LaLanne Is Back (Sort Of), Helping Viewers Feel Guilty Again.” New York Times, March 12, 2004, accessed June 14, 2017. http://www.nytimes.com/2004/03/12/sports/tv-sports-jack-lalanne-is-back-sort-ofhelping-viewers-feel-guilty-again.html.

Segman, Harriet. "Forever Young." TV Radio Mirror, June 1959: 60-63. Media History Digital Library. http://archive.org/stream/radiotv00mac\#page/60/.

Slide, Anthony. Before Video: A History of the Non-Theatrical Film. Westport, CT: Greenwood Press, 1992.

Spencer, F.G. “Zongar.” Motion Picture News, February 1918: 737. Media History Digital Library. http://archive.org/stream/motionpicturenew171unse\#page/736/.

Streible, Dan. "The Role of Orphan Films in the 21st Century Archive." Cinema Journal 46, no. 3 (2007): 124-28.

Streible, Dan. Fight Pictures: A History of Boxing and Early Cinema. Berkeley: University of California Press, 2008.

Streible, Dan. “A Pathex 9.5 mm fight picture.” The Orphan Film Symposium, May 31, 2008, accessed March 27, 2017. http://orphanfilmsymposium.blogspot.ca/2008/05/pathex-95mm-fight-picture.html.

Streible, Dan. "The State of Orphan Films.” The Moving Image 9, no. 1 (2009): vi-xix.

Streible, Dan, Martina Roepke and Anke Mebold. "Introduction: Nontheatrical Film." Film History 19, no. 4 (2007): 339-42.

“TV's Great Bust-and-Chest Boom.” Sponsor, October 1962: 42-. Media History Digital Library. http://archive.org/stream/sponsor164053spon\#page/n115/. 
Van Bogart, John W.C. Magnetic Tape Storage and Handling: A Guide for Libraries and Archives. Washington, DC: The Commission on Preservation and Access and St. Paul, MN: National Media Laboratory, 1995. https://www.clir.org/pubs/reports/pub54.

"Visual Instruction Program at Washington." Visual Education, July 1924: 205. Media History Digital Library. http://archive.org/stream/visualeducation04soci\#page/204/.

Ward, Richard Lewis. When the Cock Crows: A History of the Pathé Exchange. Carbondale, IL: Southern Illinois University Press, 2016.

Wasser, Frederick. Veni, Vidi, Video: The Hollywood Empire and the VCR. Austin: University of Texas Press, 2002.

Wasson, Haidee. "Electric Homes! Automatic Movies! Efficient Entertainment!: Domesticity and the 16mm Projector in the 1920s." Cinema Journal 48, no. 4 (2009): 1-21.

Williams, Linda. "Film Bodies: Gender, Genre, and Excess." Film Quarterly 44, no. 4 (1991): $2-13$.

Wisniewski, Timothy. "Framers of the Kept: Against the Grain Appraisal of Ephemeral Moving Images." The Moving Image 7, no. 2 (2007): 1-24.

“Wives With Hips.” Photoplay Magazine, November 1924: 123. Media History Digital Library. http://archive.org/stream/pho27chic\#page/n669/.

Yoffe, Emily. “Exercise Time Warp.” Slate, January 19, 2011, accessed April 20, 2017. http://www.slate.com/articles/life/fitness/2011/01/exercise_time_warp.html.

““Zongar’ Has Timely Appeal.” The Moving Picture World, June 1918: 1601. Media History Digital Library. http://archive.org/stream/morewor36chal\#page/n1011/. 